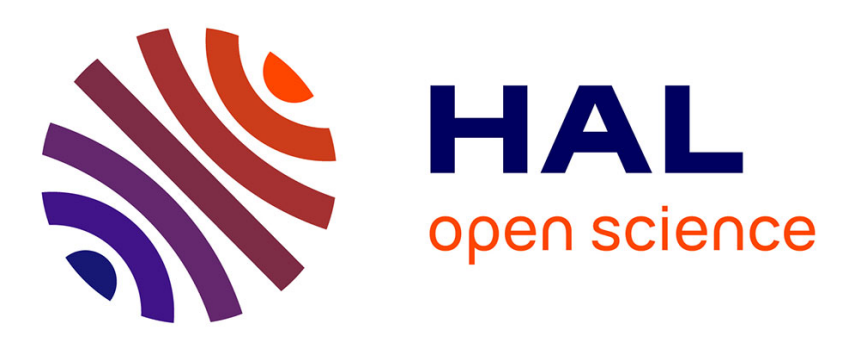

\title{
The influence of landscape spatial configuration on nitrogen and phosphorus exports in agricultural catchments
}

Antoine Casquin, Rémi Dupas, Sen Gu, Ewan Couic, Gérard Gruau, Patrick Durand

\section{To cite this version:}

Antoine Casquin, Rémi Dupas, Sen Gu, Ewan Couic, Gérard Gruau, et al.. The influence of landscape spatial configuration on nitrogen and phosphorus exports in agricultural catchments. Landscape Ecology, 2021, 36 (12), pp.3383-3399. 10.1007/s10980-021-01308-5 . insu-03325139

\section{HAL Id: insu-03325139 \\ https://hal-insu.archives-ouvertes.fr/insu-03325139}

Submitted on 17 Sep 2021

HAL is a multi-disciplinary open access archive for the deposit and dissemination of scientific research documents, whether they are published or not. The documents may come from teaching and research institutions in France or abroad, or from public or private research centers.
L'archive ouverte pluridisciplinaire HAL, est destinée au dépôt et à la diffusion de documents scientifiques de niveau recherche, publiés ou non, émanant des établissements d'enseignement et de recherche français ou étrangers, des laboratoires publics ou privés. 


\section{Landscape Ecology}

\section{The influence of landscape spatial configuration on nitrogen and phosphorus exports in agricultural catchments \\ --Manuscript Draft--}

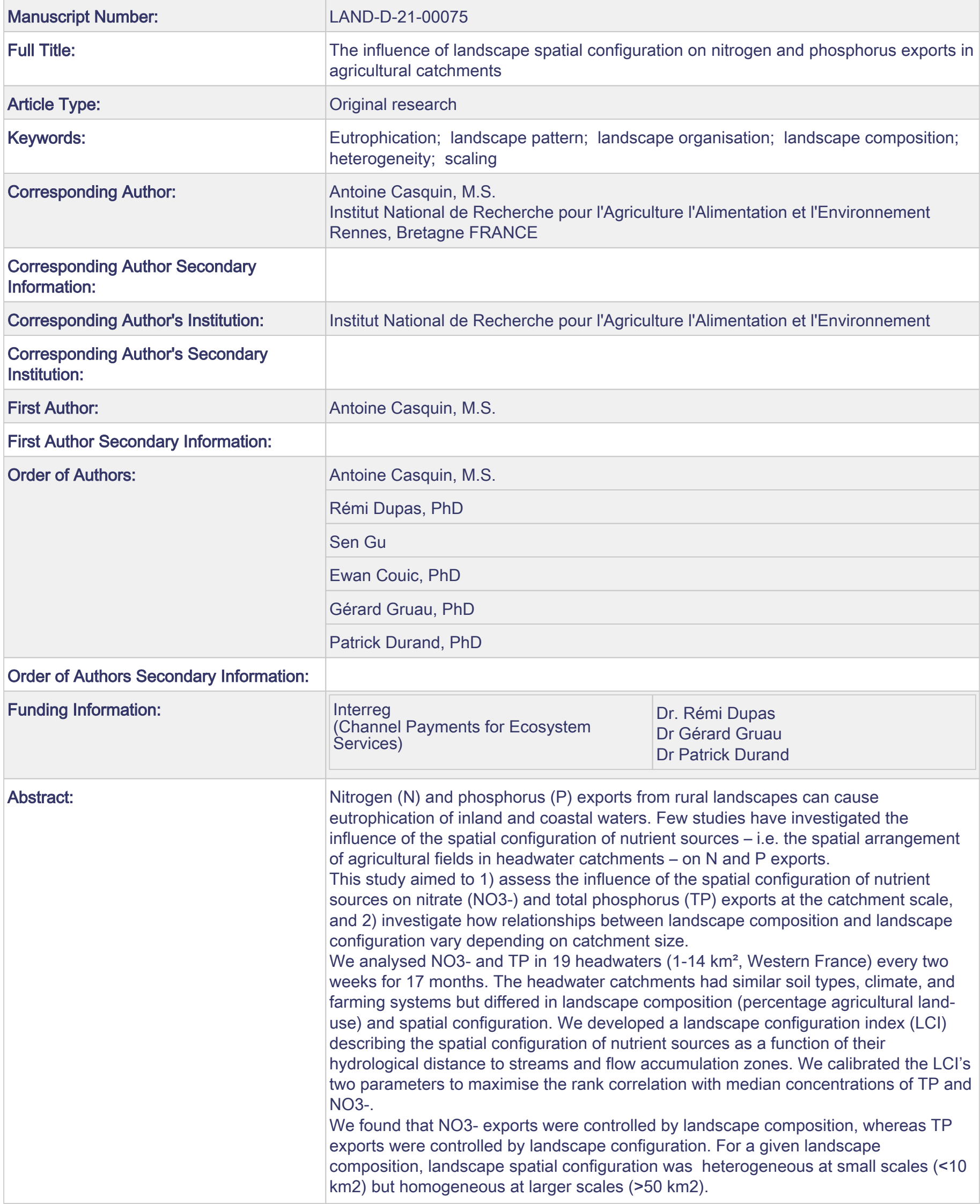


The spatial configuration of nutrient sources influences TP but not NO3- exports. An ideal placement of mitigation options to limit TP export should consider both the hydrological distance to streams and flow accumulation zones.

\section{Suggested Reviewers:}

Sarah E Godsey, PhD

PI, Idaho State University

godsey@isu.edu

Relevent work on landscape pattren and biogeochemistry of headwater streams

Erin Peterson, PhD

PI, Queensland University of Technology

erin.peterson@qut.edu.au

Research Interests:

Environmental monitoring assessment and reporting

Spatial networks

Spatial statistics

Her work on spatially explicit metrics and water quality

Jay Zarnetske, , PhD

Associate professor, Michigan State University

jpz@msu.edu

Reasearch interest : how catchment hydrology and groundwater - surface water interactions affect aquatic ecosystems through solute generation, fate, and transpor

Ian A Thomas, $\mathrm{PhD}$

Post Doc, University College Dublin

ian.thomas@ucd.ie

Specialist of critical source areas ;agricultural diffuse pollution; hydrological modelling

Philip Haygarth, PhD

Professor, Lancaster Environment Centre

p.haygarth@lancaster.ac.uk

Professor Phil Haygarth conducts research on the interface between soils and freshwaters, with a focus on diffuse (particularly phosphorus) pollution and runoff control in a catchment context.

Numerous works on scaling the phosphorus signal from land to aquatic ecosystems. 


\section{Title}

2 The influence of landscape spatial configuration on nitrogen and phosphorus exports in

3 agricultural catchments

\section{Authors}

5 Antoine Casquin. INRAE, UMR SAS 1069 / L'Institut Agro, 65 rue de St Brieuc, 35200

6 Rennes, France. antoine.casquin@inrae.fr / a.casquin@gmail.com. https://orcid.org/0000-

7 0001-6897-0183

8 Rémi Dupas. INRAE, UMR SAS 1069 / L'Institut Agro, 65 rue de St Brieuc, 35200 Rennes,

9 France. remi.dupas@inrae.fr. https://orcid.org/0000-0002-5932-4056

Sen Gu. OSUR, Géosciences Rennes, CNRS, UMR 6118, Campus de Beaulieu, 35042 Rennes, France / Institute of Hydrobiology, Chinese Academy of Sciences, Wuhan 430072 , China.gusen@ihb.ac.cn

Ewan Couic. OSUR, Géosciences Rennes, CNRS, UMR 6118, Campus de Beaulieu, 35042 Rennes, France. ewan.couic@univ-rennes1.fr. https://orcid.org/0000-0003-4223-2726

Gérard Gruau. OSUR, Géosciences Rennes, CNRS, UMR 6118, Campus de Beaulieu, 35042 Rennes, France. gerard.gruau@univ-rennes1.fr

Patrick Durand. INRAE, UMR SAS 1069 / L'Institut Agro, 65 rue de St Brieuc, 35200 Rennes, France. patrick.durand@inrae.fr. https://orcid.org/0000-0002-0984-693X

\section{Correspondent author:}

Antoine Casquin. INRAE, UMR SAS 1069 / L'Institut Agro, 65 rue de St Brieuc, 35200 Rennes, France. antoine.casquin@inrae.fr (institutional) / a.casquin@gmail.com (permanent). Tel.: +33(0)2 234854 22. Fax: + 33(0)2 23485430 .

\section{Abstract}

\section{Context}

Nitrogen $(\mathrm{N})$ and phosphorus $(\mathrm{P})$ exports from rural landscapes can cause eutrophication of inland and coastal waters. Few studies have investigated the influence of the spatial configuration of nutrient sources - i.e. the spatial arrangement of agricultural fields in headwater catchments - on $\mathrm{N}$ and $\mathrm{P}$ exports.

\section{Objectives}

This study aimed to 1) assess the influence of the spatial configuration of nutrient sources on nitrate $\left(\mathrm{NO}_{3}{ }^{-}\right)$and total phosphorus (TP) exports at the catchment scale, and 2) investigate 
32 how relationships between landscape composition and landscape configuration vary

33 depending on catchment size.

\section{Methods}

35 We analysed $\mathrm{NO}_{3}$ and TP in 19 headwaters (1-14 $\mathrm{km}^{2}$, Western France) every two weeks for 3617 months. The headwater catchments had similar soil types, climate, and farming systems

37 but differed in landscape composition (percentage agricultural land-use) and spatial 38 configuration. We developed a landscape configuration index ( $\mathrm{LCl}$ ) describing the spatial 39 configuration of nutrient sources as a function of their hydrological distance to streams and 40 flow accumulation zones. We calibrated the LCl's two parameters to maximise the rank 41 correlation with median concentrations of $\mathrm{TP}^{2}$ and $\mathrm{NO}_{3}{ }^{-}$.

\section{Results}

43 We found that $\mathrm{NO}_{3}^{-}$exports were controlled by landscape composition, whereas TP exports 44 were controlled by landscape configuration. For a given landscape composition, landscape 45 spatial configuration was highly heterogeneous at small scales $\left(<10 \mathrm{~km}^{2}\right)$ but became 46 homogeneous at larger scales $\left(>50 \mathrm{~km}^{2}\right)$.

\section{Conclusions}

48 The spatial configuration of nutrient sources influences TP but not $\mathrm{NO}_{3}{ }^{-}$exports. An ideal 49 placement of mitigation options to limit TP export should consider both the hydrological 50 distance to streams and flow accumulation zones

\section{Keywords}

53 Eutrophication; landscape pattern; landscape organisation; landscape composition; 54 heterogeneity; scaling 


\section{Introduction}

Excessive loads of nitrogen $(\mathrm{N})$ and phosphorus $(\mathrm{P})$ cause the eutrophication of marine and freshwater ecosystems (Dodds and Smith 2016; Le Moal et al. 2018), which threatens biodiversity and human activities (Steffen et al. 2015). In streams and rivers that drain agricultural landscapes, $\mathrm{N}$ and $\mathrm{P}$ originate mainly from fertilised agricultural fields. Water quality mitigation measures often result in reduced yields or increased production costs; hence, they decrease profitability for farmers (Withers et al. 2014). It is therefore necessary to locate mitigation options such as set-aside areas and buffer zones where they will be most effective (Cole et al. 2020). Mechanistic models (Casal et al. 2019; McDowell et al. 2014) and methods based on statistical analysis of landscape properties (Doody et al. 2012; Hashemi et al. 2018) have been used to optimise locations of mitigation practices.

Most $\mathrm{N}$ and $\mathrm{P}$ enter the hydrographic network in headwater streams (Dodds and Oakes 2008), which represent $90 \%$ of global stream length (Downing 2012) but are rarely monitored, except for research purposes (Bishop et al. 2008). At this scale, nutrient exports vary greatly in space (Abbott et al. 2018; Temnerud and Bishop 2005). While in large (>100 $\mathrm{km}^{2}$ ) catchments, both $\mathrm{N}$ and $\mathrm{P}$ exports can be statistically related to proxies of agricultural pressure intensity, such as percentage of agricultural land-use or agricultural surplus (Dupas et al. 2015; Goyette et al. 2018), these relationships break down at the scale of headwater catchments $\left(<20 \mathrm{~km}^{2}\right)$ (Bol et al. 2018; Burt and Pinay 2005). The reason why the relationship between landscape composition and nutrient exports is scale-dependent is unclear. Identifying the factor(s) responsible for this loss of relationship, and the characteristic spatial scale at which it occurs, would help guide water quality mitigation measures at the catchment scale. In this article, we explore the hypothesis that the spatial configuration of nutrient sources - i.e. the spatial arrangement/distribution/organisation of agricultural fields, hereafter called "landscape configuration", -influences N and P exports at the headwater catchment scale. For a given region, landscape configuration can be highly heterogeneous among headwater catchments but homogeneous among larger catchments (Abbott et al. 2018; Temnerud and Bishop 2005). If verified, these two hypotheses could explain the breakdown of the relationship between agricultural pressure intensity and nutrient exports at the headwater catchment scale.

Several authors have reviewed the influence of landscape spatial configuration on nutrient loads at multiple scales (Lintern et al. 2018; Uuemaa et al. 2007). Metrics used in landscape ecology are based on the area/density/edge, shape, isolation, interspersion, and connectivity of patches, and they have been applied to predict water quality parameters at the catchment scale (Liu et al. 2020; Shi et al. 2013; Xiao et al. 2016). However, these approaches often rely on regressions of several landscape metrics and water quality parameters, which risks 
over-fitting certain relationships and/or spurious correlations. Landscape spatial configuration can also be understood as the overlap and proximity of features such as streams, depressions, and flow accumulation areas to land-use patches (e.g. crops, forest fragments, urban fabric). In line with this concept, Peterson et al. (2011)) related parameters of stream ecological conditions to multiple spatially explicit landscape "topological" metrics and found that these spatially explicit methods clearly had more predictive power than landscape composition metrics. Staponites et al. (2019)), using similar metrics, suggested that the spatial organisation of nutrient sources (i.e. landscape configuration) influenced the transfer of reactive or labile water quality parameters (e.g. TP, $\mathrm{NO}_{2}^{-}$and $\mathrm{PO}_{4}{ }^{3-}$ ), whereas percentages of land use (i.e. landscape composition) have more predictive power for more temporally stable water quality parameters (e.g. $\mathrm{Ca}^{2+}, \mathrm{NO}_{3}{ }^{-}$, conductivity). These results are consistent with current knowledge on transfer pathways of nutrients in catchments, with deeper flowpaths for $N$ species than for $P$ species (Strohmenger et al. 2020), and explains why landscape features had less influence on $\mathrm{NO}_{3}{ }^{-}$than $\mathrm{P}$ (Thomas and Abbott 2018). These landscape metrics, however, are relatively rigid, as topological influences (e.g. hydraulic distance to stream, surface flow accumulation, slope), whether considered in the metrics or not, cannot be weighted. In addition, certain topological features vary over a much wider range of values than others, which may obscure other features when no weighting coefficient is included in the landscape metric. For example, flow accumulation (which can have large values) can overshadow the influence of slope (which varies over a narrow range of values) in an index that considers both without weighting them.

The idea that landscape configuration influences $\mathrm{N}$ and $\mathrm{P}$ loads is the basis for the concept of critical source area (CSA), i.e. the idea that a small percentage of the agricultural area (e.g. $<20 \%$ ) contributes disproportionately to the nutrients transferred to streams (e.g. $>80 \%$ ). CSAs are defined as the intersection of nutrient sources and hydrologically sensitive areas (Gburek and Sharpley 1998; Pionke et al. 2000). Initially defined at the sub-field scale, the concept of CSA was extended to larger scales; entire fields or subcatchments can also be CSAs (Buchanan et al. 2013b; Page et al. 2005; Reaney et al. 2019; Sharpley et al. 2011; Srinivasan and McDowell 2009). Substantial uncertainties remain, however, in their delineation at all scales (Doody et al. 2012). Validation at the sub-field scale can be based on observing erosion marks (Reaney et al. 2019) or tracers (Collins et al. 2012). However, studies that validate CSA delineation based on $\mathrm{N}$ or $\mathrm{P}$ concentrations in streams and rivers are rare and are based on only a few hydrologically contrasting headwater catchments (McDowell and Srinivasan 2009; Shore et al. 2014; Thomas et al. 2016a) or larger catchments for which land-use composition is already a good predictor (Giri et al. 2018). 
127 To address the limits of "expert-based" delineation of CSAs and the rigidity of spatially

128 explicit landscape metrics, we developed a stochastic, data-driven approach based on 30

129 synoptic samplings of 19 agricultural headwater catchments to answer two questions: i) Does

130 landscape configuration influence $\mathrm{N}$ and $\mathrm{P}$ exports?; and ii) Does the location of CSAs

131 depend on the hydrological distance of the nutrient source to the hydrological network, their

132 overlap with flow accumulation areas, or both? We then investigated why some relationships

133 between water quality parameters and landscape composition metrics break down below a

134 certain catchment size. For this, we studied how the relationship between landscape

135 composition and configuration varied as a function of catchment size in 500 randomly

136 selected subcatchments in the study area.

\section{2. Methods}

\section{2.1. Study site}

139 The Yvel catchment is a $375 \mathrm{~km}^{2}$ agricultural catchment of Strahler order 5 in Brittany, 140 western France (Fig. 1). The Yvel River is the main tributary of a three million $\mathrm{m}^{3}$ water 141 reservoir that has been subjected to cyanobacteria blooms since the 1970s (ODEM 2012), 142 for which $\mathrm{N}$ and $\mathrm{P}$ are deemed responsible (Shatwell and Köhler 2018). 


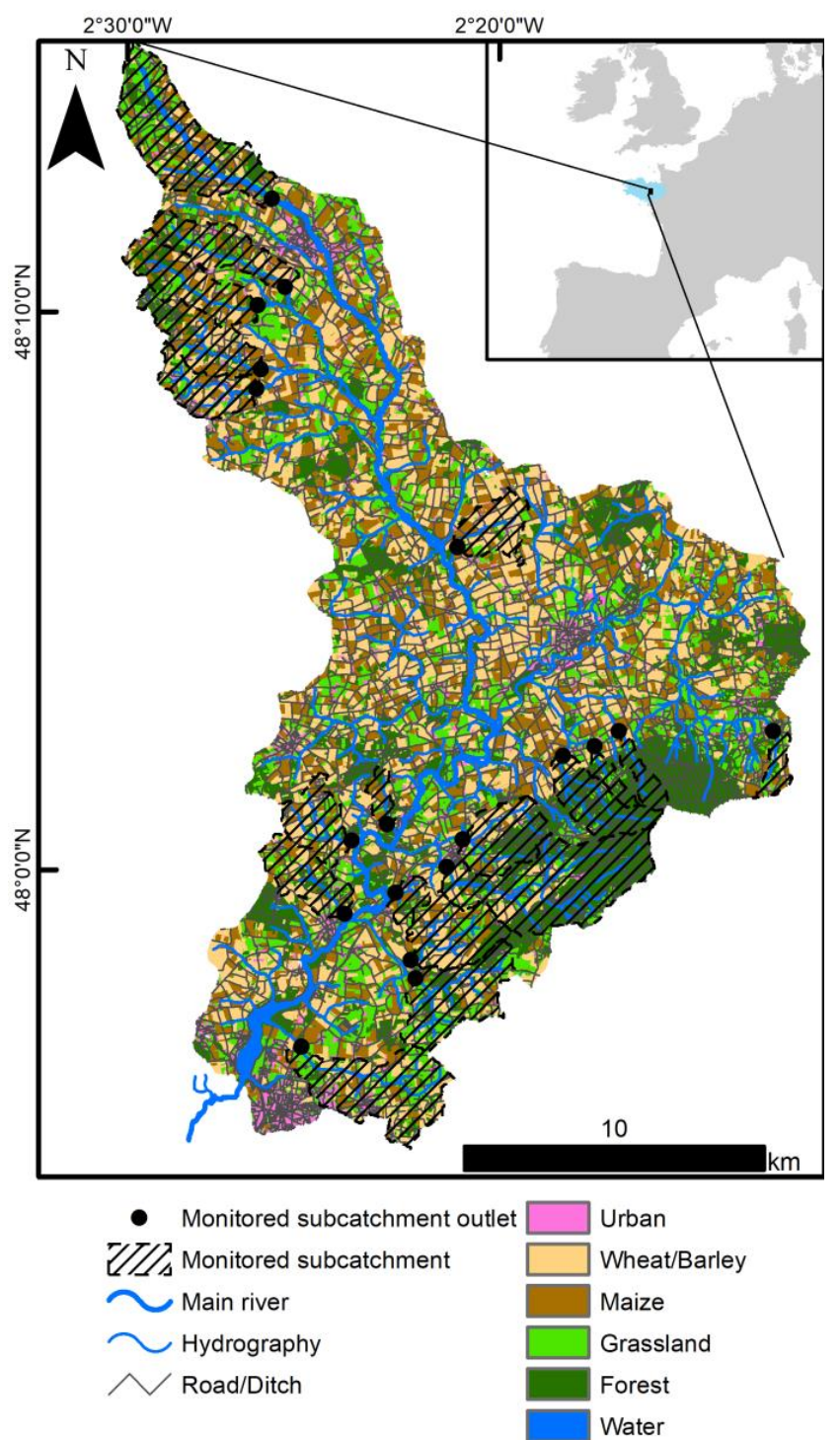

144 Fig. 1 Monitored subcatchments, land use in 2018, hydrography and roads in the Yvel 145 catchment. The inset shows the location of Brittany, France, in western Europe

146 The climate is temperate oceanic with mean annual precipitation (1998-2017) of $777 \mathrm{~mm}$ $147(\mathrm{sd}=132 \mathrm{~mm})$, mean annual temperature of $11.7^{\circ} \mathrm{C}\left(\mathrm{sd}=0.5^{\circ} \mathrm{C}\right)$, and mean annual runoff of $148254 \mathrm{~mm}$ ( $\mathrm{sd}=143 \mathrm{~mm}$ ). The Yvel River's discharge is monitored for $300 \mathrm{~km}^{2}$ of its $375 \mathrm{~km}^{2}$, 149 and monthly mean discharge varies from 157 L.s $^{-1}$ in August to 5,600 L.s ${ }^{-1}$ in February. The 150 hydrology is controlled by the dynamics of the shallow groundwater within unconsolidated 151 weathered material that caps impervious schist bedrock (Casquin et al. 2020). The land use 152 is dominated by arable fields (maize and winter cereals), which cover $54 \%$ of the catchment 153 (Fig. 1). Grasslands (21\%, mainly leys in rotation), forests (18\%), and urban areas (6\%) 154 comprise the rest of the catchment area. Hedgerow density is $71 \mathrm{~m}^{\mathrm{h}} \mathrm{ha}^{-1}$. Soils in the 155 catchment are generally shallow $(<100 \mathrm{~cm})$, are well-drained in the upland part of the 156 hillslope, and are often hydromorphic in valley bottoms. The elevation varies from 33-297 m 157 above sea level. The centre of the catchment is the flattest area (most slopes $<5 \%$ ), with long 
158

159

160

161

162

163

164

165

166

167

168

169

170

171

172

173

174

175

176

177

178

179

180

181

182

183

184

and regular hillslopes. In the north and south, the relief is more rugged, with shorter and steeper slopes. The southeast portion of the watershed of the catchment is forested and has the steepest slopes (5-15\%).

\subsection{Subcatchment monitoring}

The monitoring strategy consisted of repeated synoptic sampling of 19 subcatchments (Fig. 1). The 19 subcatchments were selected based on Strahler order (1-2), size $\left(0.8-12.6 \mathrm{~km}^{2}\right.$, mean $=5.1 \mathrm{~km}^{2}$ ), absence of a wastewater treatment plant, and accessibility. Their percentage of agricultural land-use ranged from $17-94 \%$ (mean=74\%), with mean slopes ranging from $2.7-6.6 \%$ (mean=4.9\%). Together, these 19 subcatchments covered $28 \%$ of the Yvel catchment's area. All 19 monitoring points were sampled approximately every two weeks from April 2018 to July 2019 (30 dates in total). Samples were filtered in situ immediately after sampling with cellulose acetate filters of $0.20 \mu \mathrm{m}$ pore size for nitrate $\left(\mathrm{NO}_{3}{ }^{-}\right)$ analysis. All filters were rinsed in the laboratory with $20 \mathrm{ml}$ of deionised water before use. An unfiltered water sample was also collected to analyse TP. The samples were transported to the laboratory in a cool box and then refrigerated at $4^{\circ} \mathrm{C}$ until analysis. TP was analysed within $48 \mathrm{~h}$ of sampling, while $\mathrm{NO}_{3}{ }^{-}$was analysed within one week. TP was determined colorimetrically via reaction with ammonium molybdate (Murphy and Riley 1962) after digesting the samples in acidic potassium persulfate. The precision of TP measurements was $\pm 13 \mu \mathrm{g} \cdot \mathrm{L}^{-1}$, while that of $\mathrm{NO}_{3}^{-}$concentrations, analysed by ionic chromatography (Dionex, DX120), was $\pm 4 \%$. Hydrochemical data are available at https://www.hydroshare.org/resource/7c7d7f6dd1f14450883ae1c243c3c28f/ (Dupas 2020).

\subsection{Landscape configuration index}

We developed the landscape configuration index (LCI) (Eq. 1) to test the hypothesis that the hydrological proximity of agricultural areas to watercourses and their overlap with flow accumulation areas influence nutrient exports at the headwater catchment scale. For each monitored subcatchment, the index was calculated as follows:

$$
L C I(a, b)=\frac{\frac{1}{n} \times \sum_{i=1}^{n} L U_{i} \times F A c c_{i}^{a} \times F L S_{i}^{-b}}{\frac{1}{N} \times \sum_{i=1}^{N} L U_{i} \times F A c c_{i}^{a} \times F L S_{i}^{-b}}
$$

where $a$ and $b$ are calibrated parameters, $i=1$..n are the pixels of a subcatchment; $i=1 . . N$ are the pixels of the entire catchment, $F A c c i$ is the flow accumulation on pixel $i\left(m^{2}\right), F L S i(m)$ is the distance along the surface flow line from pixel $i$ to the stream/ditch, and LUi equals 1 if pixel $i$ is a source of nutrients (i.e. an agricultural area), otherwise 0 . 
Fig. 2 details the calculations for two subcatchments with similar land-use composition, but whose LCI numerator varies by a factor of 2 when parameters $(a, b)=(1.5,1)$.

\section{Denominator calculation for $a=1.5$ and $b=1$}
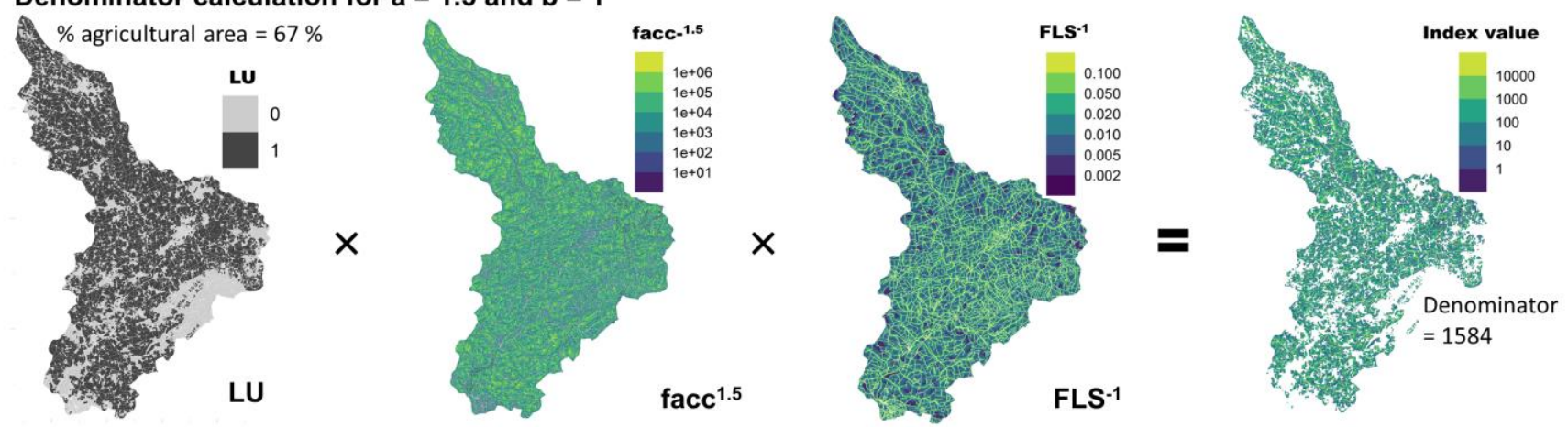

Numerator and $\mathrm{LCl}$ calculation for $\mathrm{a}=1.5$ and $b=1$

Example of agricultural subcatchments with similar landscape composition but contrasting $\mathrm{LCl}$ values
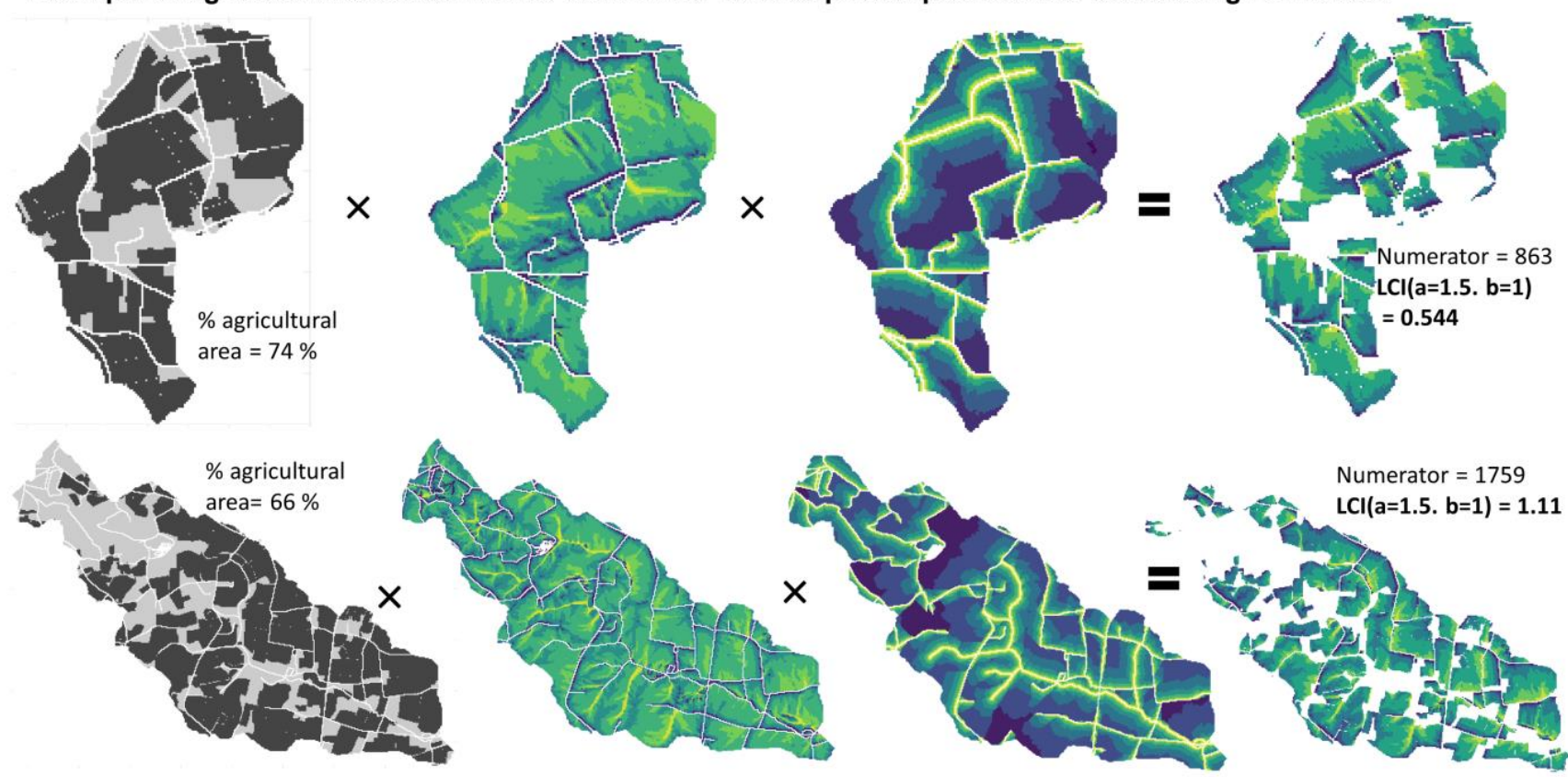

Fig. 2 Steps used to calculate the index given $a=1.5$ and $b=1.0$ for 2 of the 19 monitored subcatchments. Note the logarithmic colour scale

The denominator is a normalisation factor that corresponds to the mean value of the numerator for the entire Yvel catchment. When LCl > 1, a subcatchment's nutrient sources are located predominantly in flow accumulation zones and/or near streams. For large values of $a$ or b, the $\mathrm{LCl}$ assigns high weights to a small percentage of the area. We restricted the ranges of parameters $a$ and $b$ so that $a$ few pixels with the highest Facc and lowest FLS would not control the values of LCl. We explored the parameter space for pairs of $(a, b)$ for which the highest $5 \%$ of cumulative $\mathrm{LCl}$ in the landscape did not exceed $95 \%$ of the overall 201 cumulative $L C l$. When $b=0$, we varied a within the range $0-2$, whereas when $a=0$, we varied $b$ within the range $0-4$. 
203 By construction, when a and b equal 0 for a subcatchment, its LCl equals its percentage of 204 agricultural land-use (i.e. landscape composition) divided by the percentage of agricultural 205 land-use in the entire Yvel catchment. For other values of a and b, the LCl indicates the 206 landscape configuration. High values of parameter a increase the weight of pixels in flow 207 accumulation zones in the $\mathrm{LCl}$, while high values of parameter $\mathrm{b}$ increase the weight of pixels 208 in near-stream zones.

209

210

211

212

213

214

215

216

217

218

219

220

221

222

223

224

225

226

227

228

229

230

231

232

233

234

235

236

237

\subsection{Spatial data sources and pre-processing}

\subsubsection{Hydrographic network}

The hydrographic network consisted of both the "natural" stream network and the ditch network because 1) it is often difficult to distinguish a ditch from a rectified stream and 2) our synoptic sampling verified that most of the ditches were deep $(>1 \mathrm{~m})$ and flowed in winter (high-flow season). Ditch networks are a shortcut between agricultural areas and the "natural" river network (Ahiablame et al. 2011; Buchanan et al. 2013a). Moreover, evidence suggests that ditches act as $1^{\text {st }}$ order streams when considering nutrient spiralling and can retain and remobilise N and $P$ (Dunne et al. 2007; Hill and Robinson 2012; Smith 2009). Thus, we considered them part of the hydrographic network. We used the road network as a proxy for the ditch network, as we observed that ditches bordered all roads in the study area. Streams (permanent and intermittent) and roads were extracted from vector data (accuracy of ca. $1.5 \mathrm{~m}$ ) provided by the Institut National de I'Information Géographique et Forestière (IGN) at 1:25,000 scale. We converted these vector data to raster format and aligned them with the Digital Elevation Model (DEM) for later analysis.

\subsubsection{Digital Elevation Model}

The DEM, with a native resolution of $5 \mathrm{~m}$ (IGN 2018), was resampled to $10 \mathrm{~m}$ using cubic splines in ArcGIS 10.6. Filling was used to remove the depressions on hillslopes (Planchon and Darboux 2002), and the value "NA" was assigned to the pixels corresponding to roads and streams. We calculated flow accumulation and the hydrological distances to streams (i.e. following the surface flow paths) using the multiple flow direction algorithm (Qin et al. 2007). We chose this algorithm for its ability to generate realistic flow accumulation maps, unlike the D8 algorithm (O'Callaghan and Mark 1984).

\subsubsection{Nutrient sources}

We extracted the agricultural area from the national Land Parcel Identification System (Levavasseur et al. 2016). The data are provided as a vector dataset at the 1:5000 scale for each year since 2010 and contain field boundaries and a code that identifies the crop type. We used the 2018 dataset and verified the spatial accuracy of the agricultural area boundaries based on $50 \mathrm{~cm}$ orthophotos and the hydrography. We then rasterized this 
dataset aligned with the DEM. We assigned the value 1 to agricultural areas and 0 to nonagricultural areas. We included riparian buffer strips in agricultural areas because they are recent and have been fertilised for years, and are a well-documented legacy source of nutrients in headwater catchments (Gu et al. 2018).

\subsection{Optimisation of $(a, b)$ parameters and interpretation}

243 For each pair $(a, b)$ within the previously defined domain of exploration, we calculated 244 Spearman's rank correlation (Rs) between the $\mathrm{LCl}$ and median $\mathrm{NO}_{3}{ }^{-}$and $\mathrm{TP}$ concentrations 245 of each subcatchment (Figure 3). Since several of the subcatchments were intermittent, we 246 calculated the median concentrations for the 22 dates (out of 30) when at least 17 of the 19 subcatchments were flowing, so as not to bias calculation of the median. We focused on ranks rather than concentrations because several studies have shown that concentration estimates had high uncertainty when calculated with low-frequency data (e.g. Cassidy and Jordan 2011; Moatar et al. 2020), while the ranks of subcatchments could be predicted with high degree of confidence, as they are stable across flow conditions (Abbott et al. 2018; Dupas et al. 2019, Gu et al., 2020 - in review). The result interpretation was twofold:

- The spatial configuration of sources was considered to have an effect if Rs for at least one pair $(a, b) \neq(0,0)$ was significantly higher than that for $(a, b)=(0,0)$.

- Optimal values of $a$ and $b$ were examined to assess the relative importance of hydrological distance to streams and flow accumulation on hillslopes.

We then calculated the ratio of $\operatorname{LCl}$ with optimal $(a, b)$ to $\operatorname{LCl}$ with $(a, b)=(0,0)$ for 500 randomly selected subcatchments in the Yvel catchment, and analysed how the relationship between these two metrics evolved as catchment size increased.

\section{Results}

\subsection{Comparison of land-use composition and configuration metrics as predictors of} $\mathrm{NO}_{3}{ }^{-}$and TP concentrations in headwater catchments

Landscape composition (i.e. $\mathrm{LCl}$ with $(\mathrm{a}, \mathrm{b})=(0,0)$ ) predicted median $\mathrm{NO}_{3}$ - concentrations well (Rs=0.84, $p<0.001$ ) but not those of TP (Rs=0.33, $p=0.18)$. Varying $(a, b)$ did not substantially improved the prediction of median $\mathrm{NO}_{3}$ concentration rank; thus, landscape composition predicted $\mathrm{NO}_{3}{ }^{-}$exports well at the headwater catchment scale, and considering landscape configuration did not improve the prediction (Fig. 3A). For $\mathrm{NO}_{3}^{-}$, this result refutes our first hypothesis that the spatial configuration of nutrient sources influences nutrient exports. 


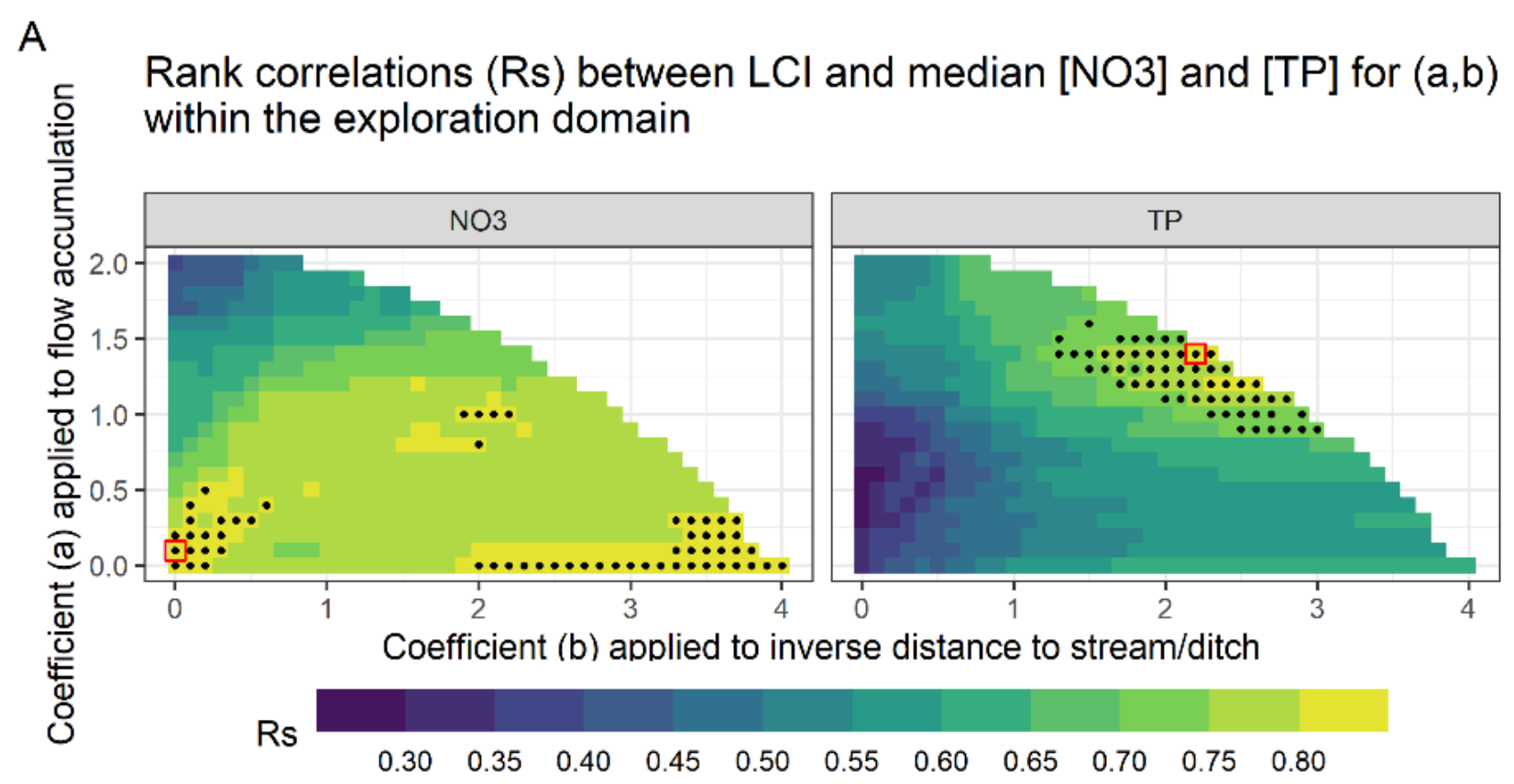

B
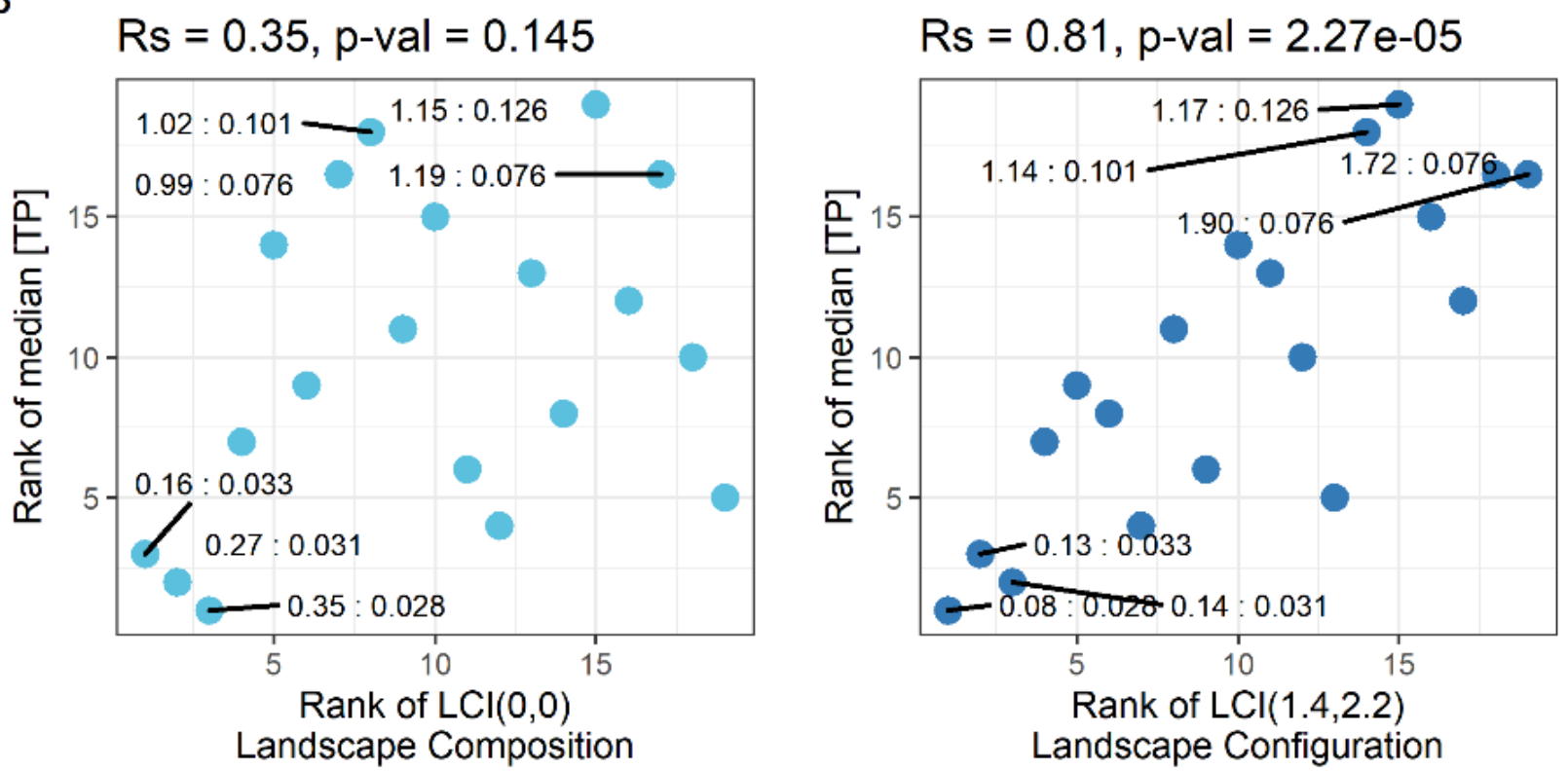

273 Fig. 3 A) Optimisation plan for parameters a and b used to predict median concentration of 274 nitrate $\left(\mathrm{NO}_{3}{ }^{-}\right)$and total phosphorus (TP) in 19 headwater catchments. Rank correlations (Rs)

275 not shown (blank) indicate $(\mathrm{a}, \mathrm{b})$ outside of the exploration domain. For each optimisation 276 plan, black dots indicate 10\% highest Rs, red square the best correlation B) Rs between 277 median [TP] and 1) landscape composition and 2) optimised landscape configuration index 278 (LCI). Annotations show LCl:median [TP] 
279 The correlation between the percentage of agricultural land and median TP concentrations $280 \quad((a, b)=(0,0))$ was $0.35(p=0.145)$ (Fig. 3B). This correlation improved as weights increased 281 for sources near streams (Rs increased as $b$ increased) and for sources that overlapped 282 surface flow accumulation (Rs increased as a increased) (Fig. 3A). This confirms our first 283 hypothesis that landscape configuration influences $\mathrm{P}$ exports, and agricultural areas near 284 watercourses and that overlap surface flow accumulation areas result in larger $\mathrm{P}$ exports. 285 The optimum correlation was obtained for $a=1.4$ and $b=2.2(R s=0.81, p<0.001)$, at the limit of 286 our field of exploration, which means that $5 \%$ of the area determined nearly $95 \%$ of the 287 index.

288 Using the same parameter exploration scheme, we optimised $(a, b)$ for TP concentrations on 289 each sampling date (Fig. $4 C$ ). The $\mathrm{LCl}$ with $(a, b) \neq(0,0)$ always predicted TP concentrations 290 better than landscape composition (Fig. 4A). The correlation between the optimised $\mathrm{LCl}$ and 291 TP concentrations differed significantly $(p<0.05)$ from 0 for all but one sampling date, except 292 during the low-flow periods (Fig. 4B). 
A

Dynamics of Rs

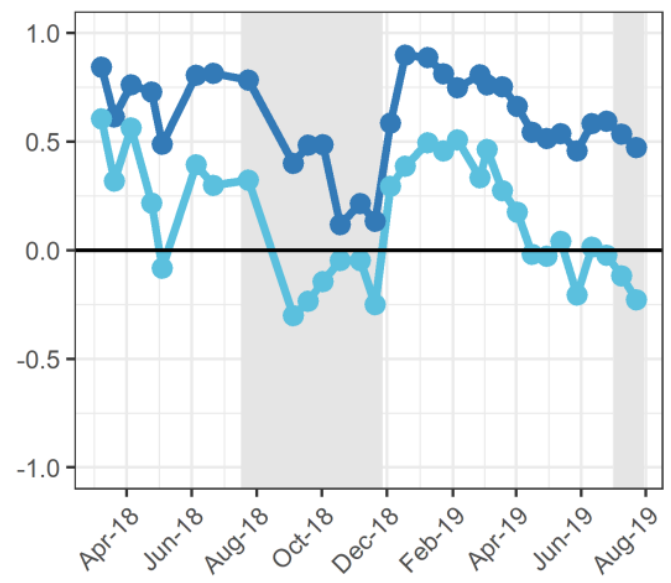

C

Optimal $(a, b)$ for LCl

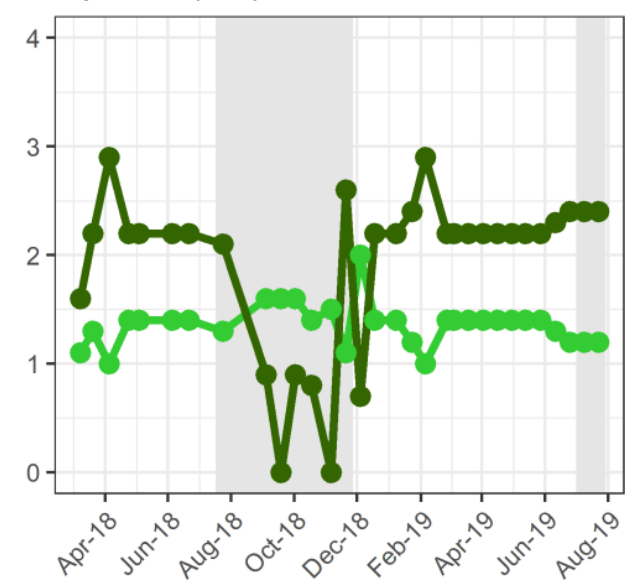

B

Dynamics of associated $p$-values

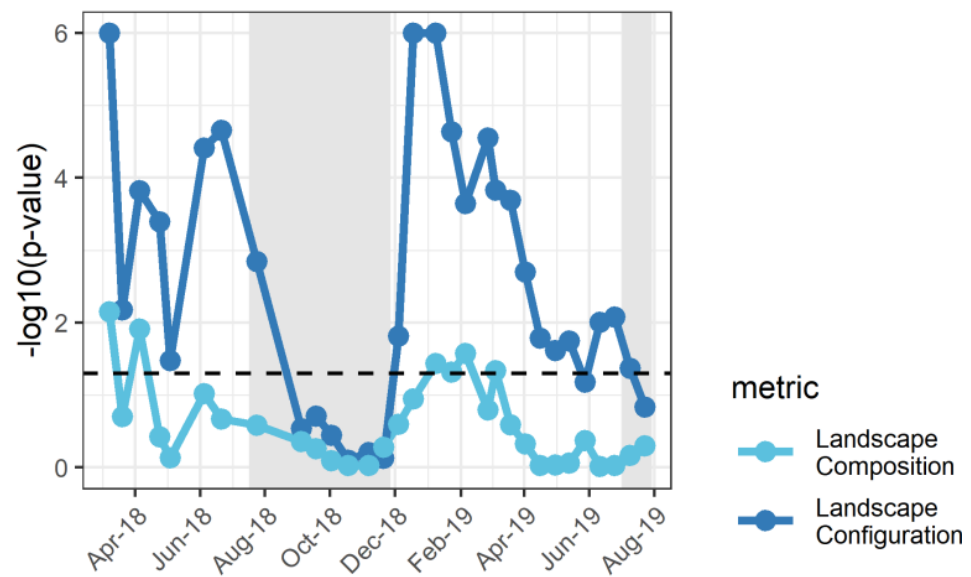

D

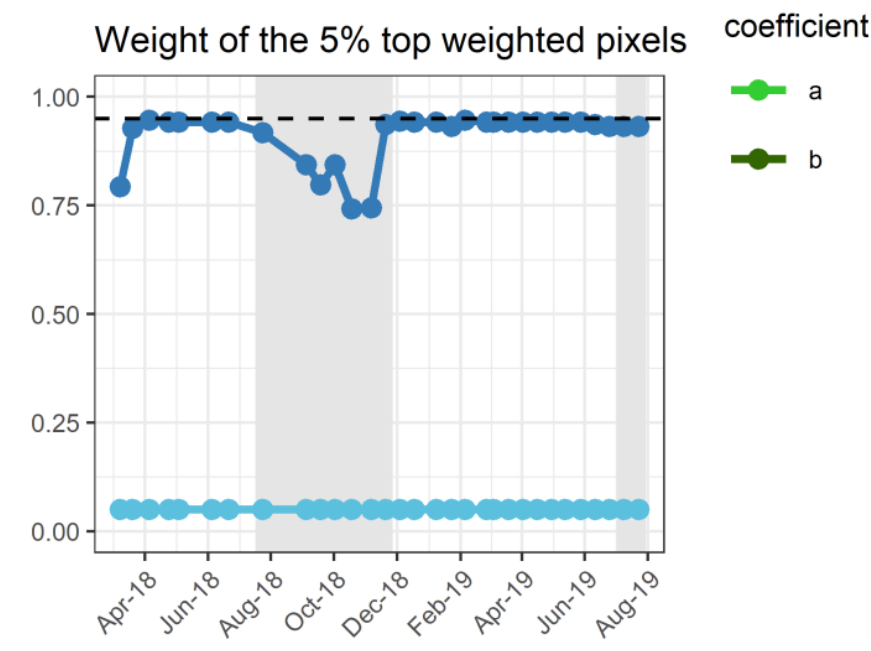

Fig. 4 Comparison of landscape composition and optimised landscape configuration index (LCl) as predictors of TP concentrations, for all sampling dates. (a) Spearman's rank correlation (Rs), (b) -log10-transformed $p$-values (dashed line indicates $p=0.05$ ), and (c) for optimised LCl, parameters $a$ and $b$ applied to flow accumulation and inverse distance to the stream/ditch (d). Relative weight of the top $5 \%$ of weighted pixels. Grey areas represent lowflow periods, when two or more sampled streams were dry

During the low-flow season (Aug-Dec 2018) and beginning of the rewetting season (Jul 2019), TP concentrations in the headwaters were not correlate with the optimised LCI ( $p>>0.05$ ) (Fig. 4B). Note that 13 of the 19 streams were dry at the peak of the low-flow season (Fig. 1S). Outside the low-flow season, optimal values of parameters a and b were stable, varying little around a median value of 1.4 and 2.2, respectively. Therefore, the total weight of the top $5 \%$ of weighted area remained close to $95 \%$ (Fig. 4D), except during the low-flow season. The optimised LCI based on median TP concentrations, hereafter referred to as LCI-TP, appears to be a robust sensitivity index to determine TP CSAs across flow conditions. 


\subsection{Spatial aggregations of the LCl-TP}

310 The data-driven optimization of the $\mathrm{LCl}$ parameters to predict the ranking of exports at the 311 catchment scale yielded an index that assigned nearly all of the weights (95\%) to small areas 312 (5\%). Most of these areas (Fig. 5A) were located near streams and ditches, but their width 313 varied. The CSAs often extended ca. $100 \mathrm{~m}$ or more into agricultural areas, especially on 314 long and convex hillslopes. Using LCI-TP values at the pixel level, we calculated LCI-TP field 315 as the mean LCl-TP of each agricultural field. The LCI-TPfield (Fig. 5B) revealed that most 316 fields were weak sources of $\mathrm{P}$ (i.e. LCI-TPfield $<<1$ ), whereas a few fields were CSAs, as their 317 LCl-TP field exceeded 10 and even 40. The associated histogram (Fig. 5C) followed a 318 lognormal distribution, which confirms the high variability at the field scale (Q5-Q95=0.001319 14.087, sd=39.05). When the LCI-TP was aggregated into $1 \mathrm{~km}^{2}$ subcatchments (LCI-TP $\left.1 \mathrm{~km} 2\right)$ 320 (Fig. 5D), its variability decreased drastically (Fig. 5F, min-max=0.17-5.38, sd=0.49). The 321 number of subcatchments with LCl-TP ${ }_{1 \mathrm{~km} 2}>1$ was approximately the same as the number of 322 subcatchments with $\mathrm{LCl}-\mathrm{TP}_{1 \mathrm{~km} 2}<1$ (Fig. $5 \mathrm{~F}$, median=0.92), but the distribution remained lognormal. Following the same pattern, the LCl-TP aggregated into $25 \mathrm{~km}^{2}$ subcatchments (LCl-TP $25 \mathrm{~km} 2)$ had even lower variability (min-max=0.71-1.36): at this scale the distribution was symmetrical (apparently normal), and no subcatchment could be considered a CSA. The information at the subfield scale (Fig. 5A) and field scale (Fig. 5B), which is relevant for

327 farmers and catchment managers, was generated for the entire study area (https://antoine328 csqn.github.io/VV1.html). 
A

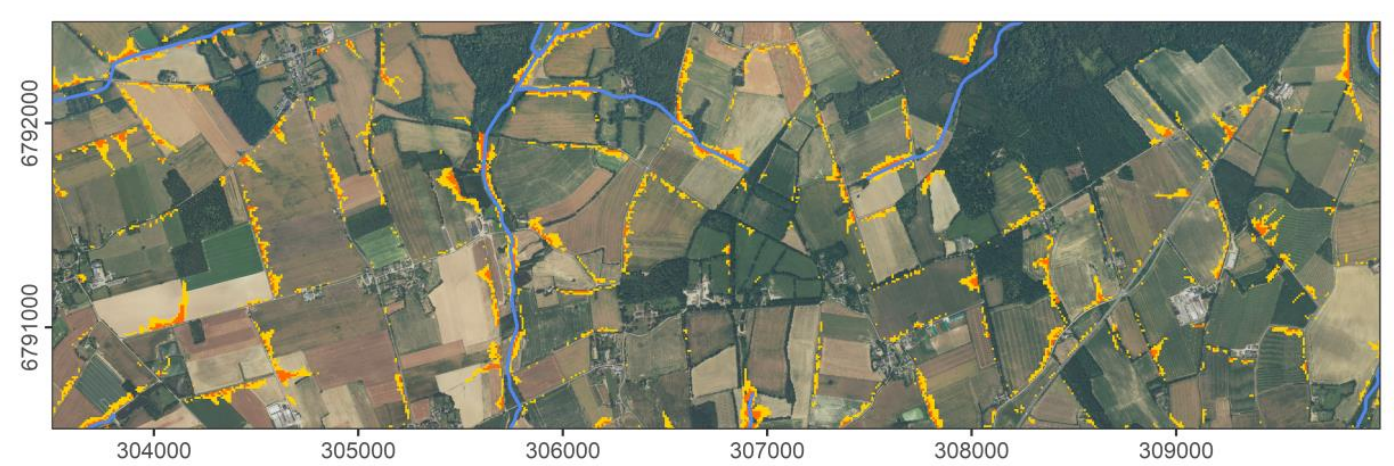

B

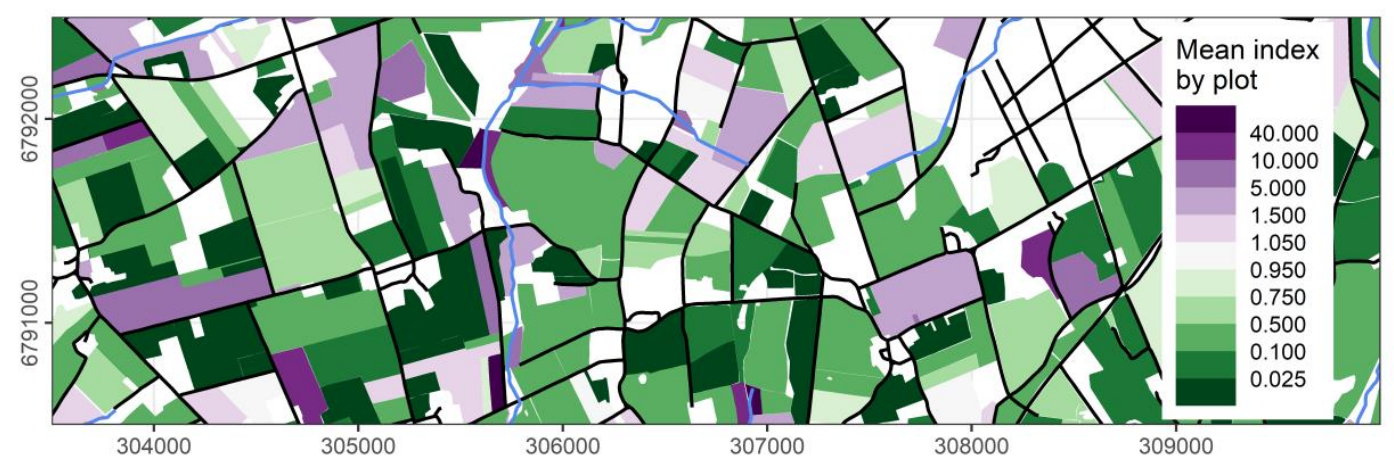

C

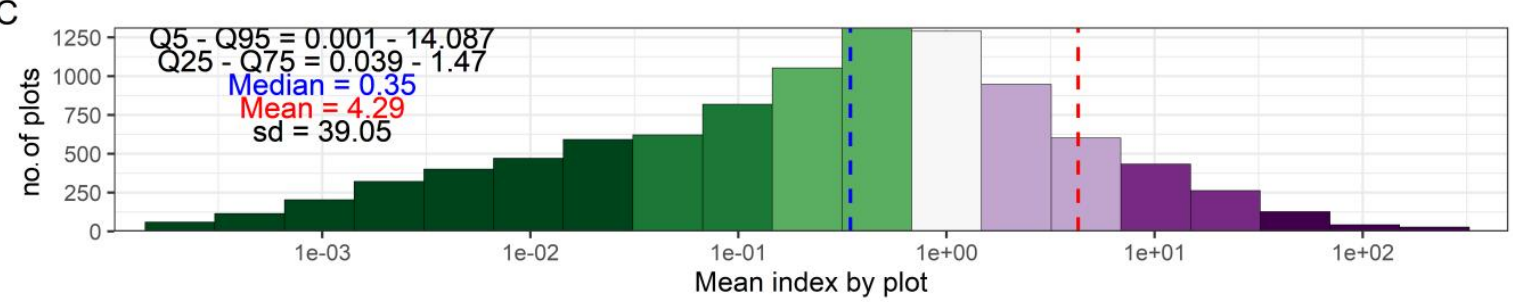

D

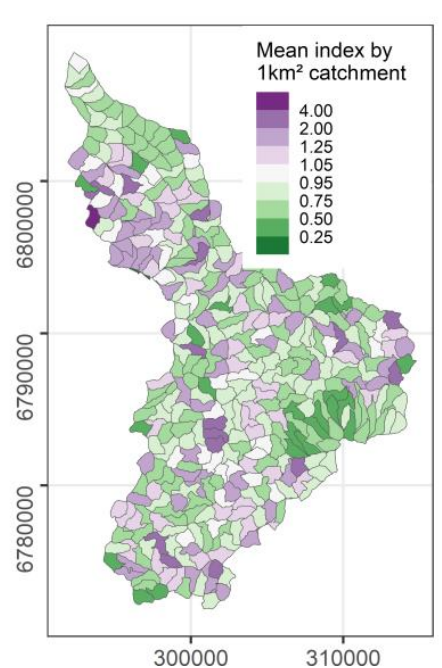

E
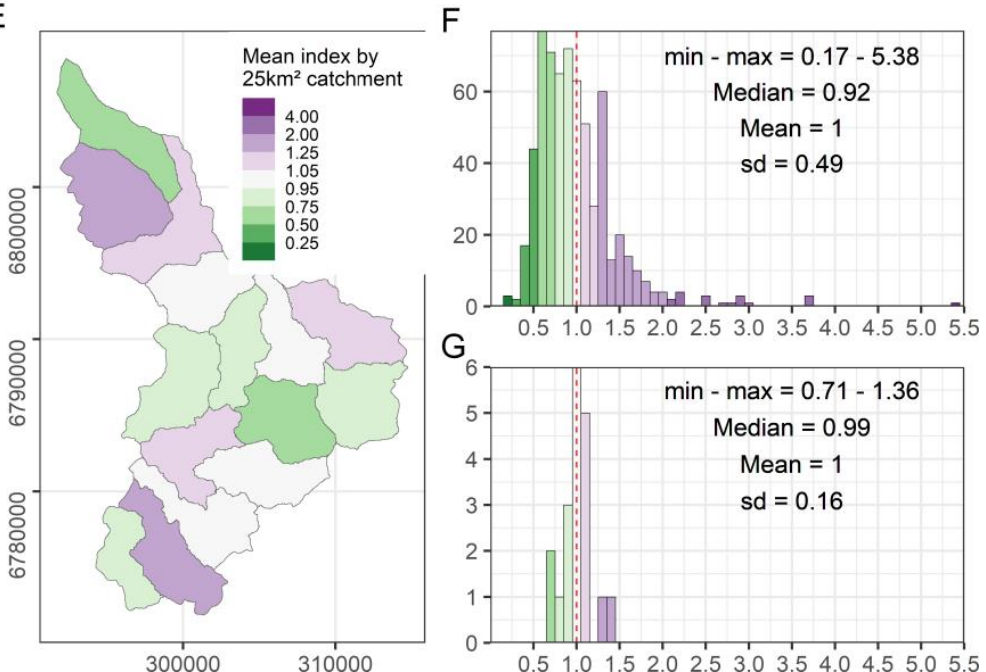

Fig. 5 A) Excerpt of the study area, ca. $6 \mathrm{~km} \times 2 \mathrm{~km}$ : top 5\% (yellow) and 1\% (red) of weighted pixels according to LCI-TP, B) Mean LCI-TP aggregated at the field scale (LCI-TP field), and C) histogram of associated values (note the log scale on the x-axis). D) LCl-TP for 1 $334 \mathrm{~km}^{2}$ subcatchments (LCl-TP $\left.\mathrm{km}_{2}\right)$ and E) $25 \mathrm{~km}^{2}$ subcatchments (LCl-TP $\left.25 \mathrm{~km} 2\right)$ and associated histograms ( $\mathrm{F}$ and $\mathrm{G}$, respectively) 


\subsection{Homogenisation of the LCI-TP with increasing catchment size}

We delineated 500 subcatchments within the study area based on 500 points randomly generated over the hydrographic network. For each subcatchment, we calculated the LCI-TP (i.e. the $L C I$ for $a=1.4$ and $b=2.2$ ), the landscape composition index (i.e. the $L C I$ for $a=b=0$ ), and their ratio, which we examined as a function of subcatchment area (Fig. 6).

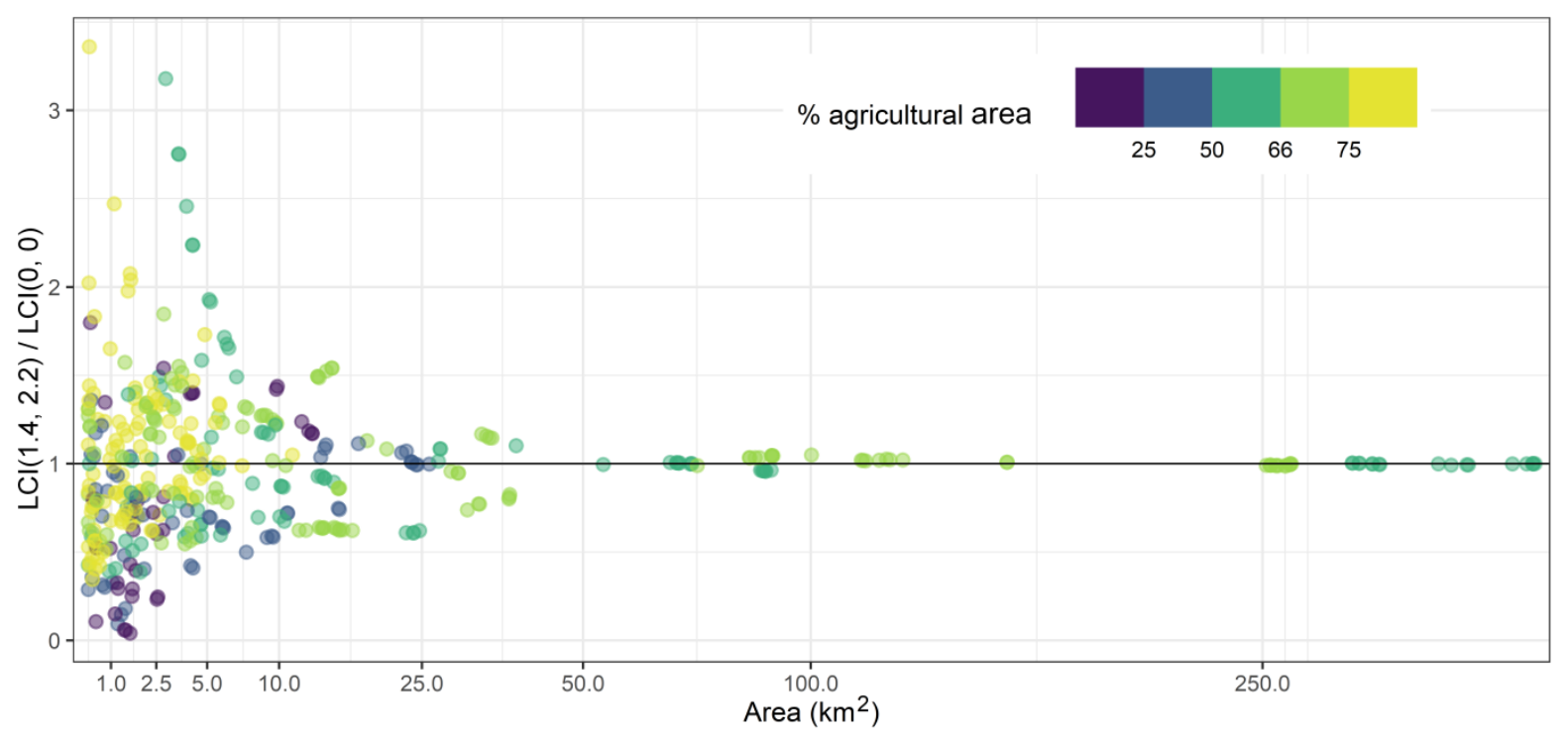

Fig. 6 Stabilisation of the ratio of the LCI-TP (landscape configuration index (LCI) for $a=1.4$ and $b=2.2$ ) to landscape composition index $(\mathrm{LCl}$ for $\mathrm{a}=\mathrm{b}=0)$ as a function of area (squareroot-transformed $x$-axis) of subcatchments in the study area (points)

This ratio varied greatly $(0.02-3.37)$ for subcatchments smaller than $10 \mathrm{~km}^{2}$, the typical size of $1^{\text {st }}$ or $2^{\text {nd }}$ order stream catchments but varied less $(0.55-1.53)$ for subcatchments of 10-50 $\mathrm{km}^{2}$. The high variability in this ratio, even for heavily farmed subcatchments, indicates that the landscape can still be optimised at this scale. For catchments larger than $50 \mathrm{~km}^{2}$, which corresponds to $4^{\text {th }}$ order rivers in the study area, the ratio converged to 1 . The main implication is that for headwater catchments $\left(<50 \mathrm{~km}^{2}\right)$ the correlation between landscape composition and configuration (as defined by the LCl-TP) is weak and non-significant (Fig. $2 S$ ), while for larger catchments the correlation is strong ( $R^{2}$ near 1) (Fig. 2S).

\section{Discussion}

\subsection{Spatial configuration of nutrient sources influences $P$ but not $\mathbf{N}$ exports} Landscape composition is a strong predictor of median $\mathrm{N}$ concentrations, while landscape configuration as defined here, seems to have no influence (Fig. 2A). This result agrees with previous research that indicates a strong correlation between metrics of agricultural $\mathrm{N}$ pressure intensity, such as $\mathrm{N}$ surplus or $\mathrm{N}$ concentrations in streams (Dupas et al. 2015; 
Kronvang et al. 2005), leaving little space for other controlling factors, such as landscape configuration. However, distributed process-based modelling of $\mathrm{N}$ fate in agricultural catchments has shown that landscape configuration can have a of second-order influence on N concentrations (Beaujouan et al. 2002; Casal et al. 2019; McDowell et al. 2014), which may not have been captured in our study. $\mathrm{P}$ concentrations are not related to landscape composition (Bol et al. 2018) or even $P$ inputs (Dupas et al. 2015; Frei et al. 2020) in headwater catchments. Multiple factors influence $\mathrm{P}$ transfers to streams: soil type and $\mathrm{P}$ content (Djodjic et al. 2004), tile-drainage (King et al. 2015a; King et al. 2015b), small ponds and hillside storage reservoirs (Schmadel et al. 2019), in-hillslope depressions (Smith and Livingston 2013), leaks from septic tanks (Withers et al. 2011) and livestock buildings, bank erosion (Kronvang et al. 2012), and ditch-dredging management (Smith and Pappas 2007). While hedgerows have little influence on $\mathrm{N}$ transfers at the catchment scale (Benhamou et al. 2013; Thomas and Abbott 2018), it is difficult to quantify their combined effects on $P$ transfers. Without considering these factors, our optimised LCl ranked the headwater catchments reasonably well according to their $\mathrm{P}$ exports (Fig. 2B), although the residuals may have been due to these other factors. We demonstrate that the spatial configuration of $P$ sources in the landscape is critical to understand $P$ transfer from land to streams in headwater catchments. The influence of the spatial configuration of nutrient sources on $\mathrm{P}$ but not $\mathrm{N}$ concentrations in agricultural headwater streams results in high variability in $\mathrm{N}: \mathrm{P}$ ratios in these ecosystems and has many consequences on stream algae communities (Pringle 1990; Stelzer and Lamberti 2001).

381 The observation that landscape spatial organisation influences $\mathrm{N}$ and $\mathrm{P}$ transfers is not new. 382 Nonetheless, our approach differs from previous studies that used single or multiple 383 regression of several landscape metrics compiled in FRAGSTATS (McGarigal and Marks 384 1995) to predict nutrient exports at the catchment scale. Despite the large body of studies that use these landscape metrics (Bu et al. 2014; Lee et al. 2009; Ouyang et al. 2014; Zhang et al. 2019), no robust cause-effect relationships emerge, and many of them give conflicting results (Wang et al. 2020). Three reasons may explain why these studies, taken together, are not conclusive: i) the many pairwise or multiple regressions between water quality parameters and landscape metrics generate spurious correlations that are not generally discussed, ii) landscape metrics depend greatly on the resolution of GIS input data, and iii) the studies do not consider the topological dimension, which is fundamental for explaining hillslope-to-stream transfers and landscape configuration (Thomas et al. 2016b). Several approaches have integrated this topological control with the hypothesis that nutrient sources near streams (Sliva and Dudley Williams 2001; Yates et al. 2014) and/or that overlap flow 
higher influence on nutrient exports than other areas. While these approaches still depend on the spatial resolution of GIS data, they are "hypothesis-driven" rather than purely "data-

398

399

400

401

402

403

404

405

406

407

408

409

410

411

412

413

414

415

416

417

418

419

420

421

422

423

424

425

426

427

428

429

430

431 driven", which decreases the risk of spurious correlations. A longstanding weakness of these approaches, however, is their rigidity due to the lack of calibrated parameters. For example, the HAiFLS index (Peterson et al. 2011) and Flow-A index (Staponites et al. 2019) included both the distance to streams and flow accumulation, but the latter dominates the index value by construction, because it varies more than the former, and neither index allows both factors to be weighted by calibrated coefficients. The stochastic approach in the LCl developed here is more flexible, and we show that both hydrological distance and flow accumulation influence $P$ transfer.

\subsection{Spatial variability and temporal stability of critical source areas}

The strongest correlation between median $\mathrm{NO}_{3}{ }^{-}$concentrations and $\mathrm{LCl}$ was for $(\mathrm{a}, \mathrm{b})=(0$, 0 ), which shows that each source (agricultural area) contributed the same, regardless of its distance to streams or overlap with flow accumulation areas. This confirms the need to consider the entire catchment to reduce $\mathrm{N}$ loads in agricultural catchments. For median $\mathrm{P}$ concentrations, the optimal was found for $(a, b)=(1.4,2.2)$, a value for which $5 \%$ of the agricultural area concentrated $95 \%$ of the weight assigned by our index at the $10 \mathrm{~m}$-pixel resolution. These values are similar to those found by Thomas et al. (2016a)), who classified 1.6-3.4\% of the catchment area (during median storm events) and $2.9-8.5 \%$ (during upperquartile events) as prone to $\mathrm{P}$ transfer, based on a CSA model that also considered land use and topography as input variables. Summing the LCI-TP at the field scale indicates that the $20 \%$ of fields at highest risk represent $85 \%$ of the total weights, which are the fields on which mitigation measures should be prioritised. The distribution is asymmetrical, with $69 \%$ of fields having a mean LCl-TP field less than 1. This information at multiple scales can be a tool to maximise ecosystem services at the catchment scale, by reorganising landscapes to decrease $\mathrm{P}$ transfer without increasing the percentage of set-aside areas (Doody et al. 2016).

The shape and location of the sub-field CSAs overlap both the mandatory riparian buffer strips (5 $\mathrm{m}$ according to local application of the European Union Nitrate Directive (DREAL 2018)) and in-hillslope CSAs based on the Topographical Wetness Index. Because most buffer strips in the study area were installed recently, we included them in P sources as they were enriched in P before conversion (Dodd and Sharpley 2016; Gu et al. 2017; Gu et al. 2018; Jarvie et al. 2017; Roberts et al. 2012). The location and shape of the CSAs indicate the need for new shapes of buffer zones, with variable widths and locations along ditches as well. Because buffer strips are critical sources of nutrients at the headwater catchment scale, they require new management practices. Potential solutions include sowing species that can 
432 capture more P (William M. Roberts 2019), mowing and exporting the residues each year 433 (Fiorellino et al. 2017), and applying amendments that have high P-sorbing ability (Borno et 434 al. 2018).

435 The temporal stability of the optimal parameters $(a, b)$ for TP during the flow period is 436 consistent with the spatial stability concept (Abbott et al. 2018), but is contrary to the concept 437 of variable source areas (Collick et al. 2015; Dahlke et al. 2012). Our interpretation of this 438 temporal stability is that even though the soil-to-stream connectivity varied temporally during 439 the sampling period, the TP concentrations observed may reflect the remobilisation of 440 sediments transferred during rare erosion events. Observing storm events that result in 441 surface transfers requires frequent observations (Cassidy and Jordan 2011). During the lowflow dates, the correlations with LCI-TP were not significant: different sources and sinks likely dominate the influence of agricultural areas and their configuration, which predominates during the flow period. Leaks from septic tanks or animal buildings and desorption from sediments are the most likely sources of $\mathrm{P}$ during this ecologically sensitive period, while hydrological disconnection, uptake, and sedimentation can be sinks of $P$ (Lannergård et al. 2020; Sandstrom et al. 2020).

4.3. Landscape homogenisation with increasing catchment size: consequences for management, monitoring, and modelling

When means were aggregated into $1 \mathrm{~km}^{2}$ subcatchments, which is the typical size of a $1^{\text {st }}$ order catchment in the study area, the LCI-TP showed high spatial variability (Fig. 5D, 5F). As mentioned, this variability decreased as the aggregation size increased (Fig. 5E, 5G), and landscape composition was weakly correlated with landscape configuration for catchments smaller than $50 \mathrm{~km}^{2}$ but strongly correlated for those larger than $50 \mathrm{~km}^{2}$ (Fig. 6, Fig. 2S). These results explain, at least partially, why relationships between water quality parameters and landscape composition metrics break down below a certain catchment size (Bol et al. 2018). They also shed light on the long-standing difficulty in scaling from nutrient export models at the field scale to those at the catchment scale: the spatial configuration of the nutrient sources can be critical.

The variability in the LCI-TP in small subcatchments and its homogenisation in larger catchments is the expression of a degree of unstructured heterogeneity (i.e. randomness) of the spatial configuration of agricultural areas (Musolff et al. 2017). Some almost entirely agricultural subcatchments have a TP sensitivity index less than 1, while some mixed-landuse catchments have a TP sensitivity index greater than 1 . The latter provides the opportunity to introduce structured heterogeneity, i.e. to reorganise agricultural activities spatially to reduce $\mathrm{P}$ transfers to streams (Musolff et al. 2017). 
These results have implications for both modelling and monitoring. Semi-distributed models that simulate $P$ exports from an entire catchment with simulation units smaller than $50 \mathrm{~km}^{2}$ should include a coefficient to represent the spatial configuration of the agricultural areas. A distributed model should consider ditches (as they are the entry point of $P$ into the hydrographic network) and, especially, the spatial variability in $\mathrm{P}$ sources. When monitoring subcatchments that are smaller than the homogenisation threshold and have similar agricultural land-use composition, the observed differences in $\mathrm{P}$ loads cannot be related directly to the agricultural practices or soil properties. The spatial configuration of agricultural areas appears to exert a major control on median $\mathrm{P}$ concentrations. This is particularly important for targeting measures to the most cost-effective fields (Doody et al. 2016) and could increase in importance due to the recent development of innovative financial tools to improve water quality, such as payment for ecosystem services schemes, whose obligation to achieve results is increasing (Hejnowicz et al. 2014). Our research provides a data-driven method to identify CSAs and thus the most cost-effective fields on which to implement mitigation measures.

The $50 \mathrm{~km}^{2}$ landscape homogenisation threshold found in this study is similar to the 18-68 $\mathrm{km}^{2}$ stream-concentration thresholds found by Abbott et al. (2018) for the Rance and HautCouesnon catchments, also located in western France. We assume that the optimised coefficients and homogenisation threshold would vary with the topo-climatic conditions and agricultural landscape characteristics. More research is needed to confirm this connection between landscape configuration and $\mathrm{P}$ loads in different environmental settings. Given the high heterogeneity of landscape configuration, this research calls for a spatially dense monitoring network of headwater catchments. We also recommend using the $\mathrm{LCl}$ to investigate the influence of landscape configuration on other water contaminants that are transferred mainly by surface flow paths, such as pesticides and faecal bacteria.

\section{Declarations}

\section{Funding}

494 The authors were supported by the Interreg project Channel Payments for Ecosystem 495 Services, funded through the European Regional Development Fund (ERDF).

\section{Conflicts of interest/Competing interests (include appropriate disclosures)}

497 The authors declare that they have no known competing financial interests or personal 498 relationships that could have appeared to influence the work reported in this paper.

\section{Ethics approval (include appropriate approvals or waivers)}

500 Not applicable 
502 Not applicable

\section{Consent for publication (include appropriate statements)}

504 All co-authors - A. Casquin, R. Dupas, S. Gu, E. Couic, G. Gruau and P. Durand - have

505 approved the manuscript and agree with its submission to Landscape Ecology

506

507

508

509

510

511

512

513

514

515

516

517

518

519

520

521

522

523

524

525

526

527

528

529

530

531

532

533

534

535

536

537

538

539

\section{Availability of data and material (data transparency)}

This study is based on a recently published dataset entitled Repeated synoptic sampling for water chemistry monitoring in the Yvel catchment, northwestern France available at https://www.hydroshare.org/resource/7c7d7f6dd1f14450883ae1c243c3c28f/ (Dupas et al. 2020). It contains the hydrochemical data and the geographic information of the study site.

\section{Code availability (software application or custom code)}

The code ( $\mathrm{R}$ script) will be made available along with the article upon acceptance on a github repository.

\section{Authors' contributions}

AC: Conceptualization, Methodology, Formal analysis, Visualization, Writing - original draft. RD: Conceptualization, Supervision, Funding acquisition. SG: Sample collection and analysis. EC: Sample collection and analysis. GG: Project administration, Funding acquisition. PD: Supervision. All authors contributed substantially to revisions.

\section{References}

Abbott BW et al. (2018) Unexpected spatial stability of water chemistry in headwater stream networks Ecol Lett 21:296-308 doi:10.1111/ele.12897

Ahiablame LM, Chaubey I, Smith DR, Engel BA (2011) Effect of tile effluent on nutrient concentration and retention efficiency in agricultural drainage ditches Agricultural Water Management 98:1271-1279 doi:10.1016/j.agwat.2011.03.002

Beaujouan V, Durand P, Ruiz L, Aurousseau P, Cotteret G (2002) A hydrological model dedicated to topography-based simulation of nitrogen transfer and transformation: rationale and application to the geomorphology- denitrification relationship Hydrological Processes 16:493-507 doi:10.1002/hyp.327

Benhamou C, Salmon-Monviola J, Durand P, Grimaldi C, Merot P (2013) Modeling the interaction between fields and a surrounding hedgerow network and its impact on water and nitrogen flows of a small watershed Agricultural Water Management 121:62-72 doi:10.1016/j.agwat.2013.01.004

Bishop K, Buffam I, Erlandsson M, Fölster J, Laudon H, Seibert J, Temnerud J (2008) Aqua Incognita: the unknown headwaters Hydrological Processes 22:1239-1242 doi:10.1002/hyp.7049

Bol R et al. (2018) Challenges of Reducing Phosphorus Based Water Eutrophication in the Agricultural Landscapes of Northwest Europe Frontiers in Marine Science 5 doi:10.3389/fmars.2018.00276 
Borno ML, Muller-Stover DS, Liu F (2018) Contrasting effects of biochar on phosphorus dynamics and bioavailability in different soil types Sci Total Environ 627:963-974 doi:10.1016/j.scitotenv.2018.01.283

Bu H, Meng W, Zhang Y, Wan J (2014) Relationships between land use patterns and water quality in the Taizi River basin, China Ecological Indicators 41:187-197 doi:10.1016/j.ecolind.2014.02.003

Buchanan B, Easton ZM, Schneider RL, Walter MT (2013a) Modeling the hydrologic effects of roadside ditch networks on receiving waters Journal of Hydrology 486:293-305 doi:10.1016/j.jhydrol.2013.01.040

Buchanan BP, Archibald JA, Easton ZM, Shaw SB, Schneider RL, Walter MT (2013b) A phosphorus index that combines critical source areas and transport pathways using a travel time approach Journal of Hydrology 486:123-135 doi:10.1016/j.jhydrol.2013.01.018

Burt TP, Pinay G (2005) Linking hydrology and biogeochemistry in complex landscapes Progress in Physical Geography: Earth and Environment 29:297-316 doi:10.1191/0309133305pp450ra

Casal L, Durand P, Akkal-Corfini N, Benhamou C, Laurent F, Salmon-Monviola J, Vertès F (2019) Optimal location of set-aside areas to reduce nitrogen pollution: a modelling study The Journal of Agricultural Science 156:1090-1102 doi:10.1017/s0021859618001144

Casquin A, Gu S, Dupas R, Petitjean P, Gruau G, Durand P (2020) River network alteration of C-N-P dynamics in a mesoscale agricultural catchment Sci Total Environ 749:141551 doi:10.1016/j.scitotenv.2020.141551

Cassidy R, Jordan P (2011) Limitations of instantaneous water quality sampling in surfacewater catchments: Comparison with near-continuous phosphorus time-series data Journal of Hydrology 405:182-193 doi:10.1016/j.jhydrol.2011.05.020

Cole LJ, Stockan J, Helliwell R (2020) Managing riparian buffer strips to optimise ecosystem services: A review Agriculture Ecosystems \& Environment 296 doi:10.1016/j.agee.2020.106891

Collick AS et al. (2015) Predicting phosphorus dynamics in complex terrains using a variable source area hydrology model Hydrological Processes 29:588-601 doi:10.1002/hyp.10178

Collins AL, Zhang Y, McChesney D, Walling DE, Haley SM, Smith P (2012) Sediment source tracing in a lowland agricultural catchment in southern England using a modified procedure combining statistical analysis and numerical modelling Sci Total Environ 414:301-317 doi:10.1016/j.scitotenv.2011.10.062

Dahlke HE, Easton ZM, Lyon SW, Todd Walter M, Destouni G, Steenhuis TS (2012) Dissecting the variable source area concept - Subsurface flow pathways and water mixing processes in a hillslope Journal of Hydrology 420-421:125-141 doi:10.1016/j.jhydrol.2011.11.052

Djodjic F, Borling K, Bergstrom L (2004) Phosphorus leaching in relation to soil type and soil phosphorus content J Environ Qual 33:678-684 doi:10.2134/jeq2004.6780

Dodd RJ, Sharpley AN (2016) Conservation practice effectiveness and adoption: unintended consequences and implications for sustainable phosphorus management Nutrient Cycling in Agroecosystems 104:373-392 doi:10.1007/s10705-015-9748-8

Dodds W, Smith V (2016) Nitrogen, phosphorus, and eutrophication in streams Inland Waters 6:155-164 doi:10.5268/iw-6.2.909

Dodds WK, Oakes RM (2008) Headwater influences on downstream water quality Environ Manage 41:367-377 doi:10.1007/s00267-007-9033-y

Doody DG, Archbold M, Foy RH, Flynn R (2012) Approaches to the implementation of the Water Framework Directive: targeting mitigation measures at critical source areas of diffuse phosphorus in Irish catchments J Environ Manage 93:225-234 doi:10.1016/j.jenvman.2011.09.002

Doody DG et al. (2016) Optimizing land use for the delivery of catchment ecosystem services Frontiers in Ecology and the Environment 14:325-332 doi:10.1002/fee.1296 
Downing $J$ (2012) Global abundance and size distribution of streams and rivers Inland Waters 2:229-236 doi:10.5268/iw-2.4.502

DREAL B (2018) Directive nitrates 5ème programme d'actions en Bretagne. http://www.bretagne.developpement-durable.gouv.fr/cinquieme-programme-dactions-regional-directive-r837.html[Online]. Accessed 11 January 2021

Dunne EJ, Mckee KA, Clark MW, Grunwald S, Reddy KR (2007) Phosphorus in agricultural ditch soil and potential implications for water quality Journal of Soil and Water Conservation 62:244-252

Dupas R, Delmas M, Dorioz J-M, Garnier J, Moatar F, Gascuel-Odoux C (2015) Assessing the impact of agricultural pressures on $\mathrm{N}$ and $\mathrm{P}$ loads and eutrophication risk Ecological Indicators 48:396-407 doi:10.1016/j.ecolind.2014.08.007

Dupas R, Minaudo C, Abbott BW (2019) Stability of spatial patterns in water chemistry across temperate ecoregions Environmental Research Letters 14:074015 doi:10.1088/1748-9326/ab24f4

Dupas R, S. Gu, A. Casquin, G. Gruau, P. Petitjean, P. Durand (2020) Repeated synoptic sampling for water chemistry monitoring in the Yvel catchment, northwestern France url:http://www.hydroshare.org/resource/7c7d7f6dd1f14450883ae1c243c3c28f

Fiorellino N, Kratochvil R, Coale F (2017) Long-Term Agronomic Drawdown of Soil Phosphorus in Mid-Atlantic Coastal Plain Soils Agronomy Journal 109:455-461 doi:10.2134/agronj2016.07.0409

Frei RJ et al. (2020) Predicting Nutrient Incontinence in the Anthropocene at Watershed Scales Frontiers in Environmental Science 7 doi:10.3389/fenvs.2019.00200

Gburek WJ, Sharpley AN (1998) Hydrologic Controls on Phosphorus Loss from Upland Agricultural Watersheds Journal of Environmental Quality 27:267-277 doi:10.2134/jeq1998.00472425002700020005x

Giri S, Qiu Z, Zhang Z (2018) Assessing the impacts of land use on downstream water quality using a hydrologically sensitive area concept Journal of Environmental Management 213:309-319 doi:10.1016/j.jenvman.2018.02.075

Goyette J-O, Bennett EM, Maranger R (2018) Differential influence of landscape features and climate on nitrogen and phosphorus transport throughout the watershed Biogeochemistry 142:155-174 doi:10.1007/s10533-018-0526-y

Gu $S$ et al. (2017) Release of dissolved phosphorus from riparian wetlands: Evidence for complex interactions among hydroclimate variability, topography and soil properties Sci Total Environ 598:421-431 doi:10.1016/j.scitotenv.2017.04.028

Gu S, Gruau G, Malique F, Dupas R, Petitjean P, Gascuel-Odoux C (2018) Drying/rewetting cycles stimulate release of colloidal-bound phosphorus in riparian soils Geoderma 321:32-41 doi:10.1016/j.geoderma.2018.01.015

Hashemi F, Olesen JE, Hansen AL, Borgesen CD, Dalgaard T (2018) Spatially differentiated strategies for reducing nitrate loads from agriculture in two Danish catchments $\mathrm{J}$ Environ Manage 208:77-91 doi:10.1016/j.jenvman.2017.12.001

Hejnowicz AP, Raffaelli DG, Rudd MA, White PCL (2014) Evaluating the outcomes of payments for ecosystem services programmes using a capital asset framework Ecosystem Services 9:83-97 doi:10.1016/j.ecoser.2014.05.001

Hill CR, Robinson JS (2012) Phosphorus flux from wetland ditch sediments Sci Total Environ 437:315-322 doi:10.1016/j.scitotenv.2012.06.109

IGN (2018) RGE ALTI Version 2.0 Les Modèles numériques 3D url: https://geoservices.ign.fr/ressources_documentaires/Espace_documentaire/MODELE S_3D/RGE_ALT/DL_RGEALTI_2-0.pdf. Accessed 11 January 2021

Jarvie $H \bar{P}$, Johnson LT, Sharpley AN, Smith DR, Baker DB, Bruulsema TW, Confesor R (2017) Increased Soluble Phosphorus Loads to Lake Erie: Unintended Consequences of Conservation Practices? J Environ Qual 46:123-132 doi:10.2134/jeq2016.07.0248 
King KW, Williams MR, Fausey NR (2015a) Contributions of systematic tile drainage to watershed-scale phosphorus transport J Environ Qual 44:486-494 doi:10.2134/jeq2014.04.0149

King KW et al. (2015b) Phosphorus transport in agricultural subsurface drainage: a review J Environ Qual 44:467-485 doi:10.2134/jeq2014.04.0163

Kronvang B, Audet J, Baattrup-Pedersen A, Jensen HS, Larsen SE (2012) Phosphorus load to surface water from bank erosion in a Danish lowland river basin J Environ Qual 41:304-313 doi:10.2134/jeq2010.0434

Kronvang B, Jeppesen E, Conley DJ, Søndergaard M, Larsen SE, Ovesen NB, Carstensen J (2005) Nutrient pressures and ecological responses to nutrient loading reductions in Danish streams, lakes and coastal waters Journal of Hydrology 304:274-288 doi:10.1016/j.jhydrol.2004.07.035

Lannergård EE, Agstam-Norlin O, Huser BJ, Sandström S, Rakovic J, Futter MN (2020) New Insights Into Legacy Phosphorus From Fractionation of Streambed Sediment Journal of Geophysical Research: Biogeosciences 125 doi:10.1029/2020jg005763

Le Moal M et al. (2018) Eutrophication: A new wine in an old bottle? Sci Total Environ 651:111 doi:10.1016/j.scitotenv.2018.09.139

Lee S-W, Hwang S-J, Lee S-B, Hwang H-S, Sung H-C (2009) Landscape ecological approach to the relationships of land use patterns in watersheds to water quality characteristics Landscape and Urban Planning 92:80-89 doi:10.1016/j.landurbplan.2009.02.008

Levavasseur F et al. (2016) RPG Explorer: A new tool to ease the analysis of agricultural landscape dynamics with the Land Parcel Identification System Computers and Electronics in Agriculture 127:541-552 doi:10.1016/j.compag.2016.07.015

Lintern $A$ et al. (2018) Key factors influencing differences in stream water quality across space Wiley Interdisciplinary Reviews: Water 5:e1260 doi:10.1002/wat2.1260

Liu J, Liu X, Wang Y, Li Y, Jiang Y, Fu Y, Wu J (2020) Landscape composition or configuration: which contributes more to catchment hydrological flows and variations? Landsc Ecol 35:1531-1551 doi:10.1007/s10980-020-01035-3

McDowell RW, Moreau P, Salmon-Monviola J, Durand P, Leterme P, Merot P (2014) Contrasting the spatial management of nitrogen and phosphorus for improved water quality: Modelling studies in New Zealand and France European Journal of Agronomy 57:52-61 doi:10.1016/j.eja.2013.09.011

McDowell RW, Srinivasan MS (2009) Identifying critical source areas for water quality: 2. Validating the approach for phosphorus and sediment losses in grazed headwater catchments Journal of Hydrology 379:68-80 doi:10.1016/j.jhydrol.2009.09.045

McGarigal K, Marks BJ (1995) FRAGSTATS: spatial pattern analysis program for quantifying landscape structure vol 351. doi:10.2737/PNW-GTR-351

Moatar F et al. (2020) Stream Solutes and Particulates Export Regimes: A New Framework to Optimize Their Monitoring Frontiers in Ecology and Evolution 7 doi:10.3389/fevo.2019.00516

Murphy J, Riley JP (1962) A modified single solution method for the determination of phosphate in natural waters Analytica Chimica Acta 27:31-36 doi:10.1016/s00032670(00)88444-5

Musolff A, Fleckenstein JH, Rao PSC, Jawitz JW (2017) Emergent archetype patterns of coupled hydrologic and biogeochemical responses in catchments Geophysical Research Letters 44:4143-4151 doi:10.1002/2017gl072630

O'Callaghan JF, Mark DM (1984) The extraction of drainage networks from digital elevation data Computer Vision, Graphics, and Image Processing 28:323-344 doi:10.1016/s0734-189x(84)80011-0

ODEM (2012) Apports de phosphore et proliférations de cyanobactéries dans le Lac au Duc (Morbihan).

Ouyang W, Song K, Wang X, Hao F (2014) Non-point source pollution dynamics under longterm agricultural development and relationship with landscape dynamics Ecological Indicators 45:579-589 doi:10.1016/j.ecolind.2014.05.025 
Page T et al. (2005) Spatial variability of soil phosphorus in relation to the topographic index and critical source areas: sampling for assessing risk to water quality J Environ Qual 34:2263-2277 doi:10.2134/jeq2004.0398

Peterson EE, Sheldon F, Darnell R, Bunn SE, Harch BD (2011) A comparison of spatially explicit landscape representation methods and their relationship to stream condition Freshwater Biology 56:590-610 doi:10.1111/j.1365-2427.2010.02507.x

Pionke HB, Gburek WJ, Sharpley AN (2000) Critical source area controls on water quality in an agricultural watershed located in the Chesapeake Basin Ecological Engineering 14:325-335 doi:10.1016/s0925-8574(99)00059-2

Planchon O, Darboux F (2002) A fast, simple and versatile algorithm to fill the depressions of digital elevation models Catena 46:159-176

Pringle CM (1990) Nutrient Spatial Heterogeneity: Effects on Community Structure, Physiognomy, and Diversity of Stream Algae Ecology 71:905-920 doi:10.2307/1937362

Qin C, Zhu AX, Pei T, Li B, Zhou C, Yang L (2007) An adaptive approach to selecting a flowpartition exponent for a multiple-flow-direction algorithm International Journal of Geographical Information Science 21:443-458 doi:10.1080/13658810601073240

Reaney SM, Mackay EB, Haygarth PM, Fisher M, Molineux A, Potts M, Benskin CMH (2019) Identifying critical source areas using multiple methods for effective diffuse pollution mitigation J Environ Manage 250:109366 doi:10.1016/j.jenvman.2019.109366

Roberts WM, Stutter Ml, Haygarth PM (2012) Phosphorus retention and remobilization in vegetated buffer strips: a review J Environ Qual 41:389-399 doi:10.2134/jeq2010.0543

Sandstrom S, Futter MN, Kyllmar K, Bishop K, O'Connell DW, Djodjic F (2020) Particulate phosphorus and suspended solids losses from small agricultural catchments: Links to stream and catchment characteristics Sci Total Environ 711:134616 doi:10.1016/j.scitotenv.2019.134616

Schmadel NM, Harvey JW, Schwarz GE, Alexander RB, Gomez-Velez JD, Scott D, Ator SW (2019) Small Ponds in Headwater Catchments Are a Dominant Influence on Regional Nutrient and Sediment Budgets Geophysical Research Letters 46:9669-9677 doi:10.1029/2019gl083937

Sharpley AN, Kleinman PJA, Flaten DN, Buda AR (2011) Critical source area management of agricultural phosphorus: experiences, challenges and opportunities Water Science and Technology 64:945-952 doi:10.2166/wst.2011.712

Shatwell T, Köhler J (2018) Decreased nitrogen loading controls summer cyanobacterial blooms without promoting nitrogen-fixing taxa: Long-term response of a shallow lake Limnol Oceanogr 64 doi:10.1002/no.11002

Shi ZH, Ai L, Li X, Huang XD, Wu GL, Liao W (2013) Partial least-squares regression for linking land-cover patterns to soil erosion and sediment yield in watersheds Journal of Hydrology 498:165-176 doi:10.1016/j.jhydrol.2013.06.031

Shore M, Jordan P, Mellander PE, Kelly-Quinn M, Wall DP, Murphy PN, Melland AR (2014) Evaluating the critical source area concept of phosphorus loss from soils to waterbodies in agricultural catchments Sci Total Environ 490:405-415 doi:10.1016/j.scitotenv.2014.04.122

Sliva L, Dudley Williams D (2001) Buffer Zone versus Whole Catchment Approaches to Studying Land Use Impact on River Water Quality Water Research 35:3462-3472 doi:10.1016/s0043-1354(01)00062-8

Smith DR (2009) Assessment of in-stream phosphorus dynamics in agricultural drainage ditches Sci Total Environ 407:3883-3889 doi:10.1016/j.scitotenv.2009.02.038

Smith DR, Livingston SJ (2013) Managing farmed closed depressional areas using blind inlets to minimize phosphorus and nitrogen losses Soil Use and Management 29:94102 doi:10.1111/j.1475-2743.2012.00441.x

Smith DR, Pappas EA (2007) Effect of ditch dredging on the fate of nutrients in deep drainage ditches of the Midwestern United States Journal of Soil and Water Conservation 62:252-261 
Srinivasan MS, McDowell RW (2009) Identifying critical source areas for water quality: 1. Mapping and validating transport areas in three headwater catchments in Otago, New Zealand Journal of Hydrology 379:54-67 doi:10.1016/j.jhydrol.2009.09.044

Staponites LR, Bartak V, Bily M, Simon OP (2019) Performance of landscape composition metrics for predicting water quality in headwater catchments Sci Rep 9:14405 doi:10.1038/s41598-019-50895-6

Steffen W et al. (2015) Sustainability. Planetary boundaries: guiding human development on a changing planet Science 347:1259855 doi:10.1126/science.1259855

Stelzer RS, Lamberti GA (2001) Effects of N: P ratio and total nutrient concentration on stream periphyton community structure, biomass, and elemental composition Limnol Oceanogr 46:356-367 doi:10.4319/lo.2001.46.2.0356

Strohmenger $L$ et al. (2020) Multitemporal Relationships Between the Hydroclimate and Exports of Carbon, Nitrogen, and Phosphorus in a Small Agricultural Watershed Water Resources Research 56 doi:10.1029/2019wr026323

Temnerud J, Bishop K (2005) Spatial variation of streamwater chemistry in two Swedish boreal catchments: implications for environmental assessment Environ Sci Technol 39:1463-1469 doi:10.1021/es040045q

Thomas IA et al. (2016a) A sub-field scale critical source area index for legacy phosphorus management using high resolution data Agriculture, Ecosystems \& Environment 233:238-252 doi:10.1016/j.agee.2016.09.012

Thomas Z, Abbott BW (2018) Hedgerows reduce nitrate flux at hillslope and catchment scales via root uptake and secondary effects $J$ Contam Hydrol 215:51-61 doi:10.1016/j.jconhyd.2018.07.002

Thomas Z, Abbott BW, Troccaz O, Baudry J, Pinay G (2016b) Proximate and ultimate controls on carbon and nutrient dynamics of small agricultural catchments Biogeosciences 13:1863-1875 doi:10.5194/bg-13-1863-2016

Uuemaa E, Roosaare J, Mander Ü (2007) Landscape metrics as indicators of river water quality at catchment scale Hydrology Research 38:125-138 doi:10.2166/nh.2007.002

Wang M, Wang Y, Li Y, Liu X, Liu J, Wu J (2020) Natural and anthropogenic determinants of riverine phosphorus concentration and loading variability in subtropical agricultural $\begin{array}{lllll}\text { catchments Agriculture Ecosystems \& } & \text { Environment } & 287\end{array}$ doi:10.1016/j.agee.2019.106713

William M. Roberts TSG, Marc I. Stutter, Aránzazu Louro, Mustafa Ali, Philip M. Haygarth (2019) Phosphorus leaching from riparian soils with differing management histories under three grass species doi:10.2134/jeq2019.07.0252

Withers P, Neal C, Jarvie H, Doody D (2014) Agriculture and Eutrophication: Where Do We Go from Here? Sustainability 6:5853-5875 doi:10.3390/su6095853

Withers PJ, Jarvie HP, Stoate C (2011) Quantifying the impact of septic tank systems on eutrophication risk in rural headwaters Environ Int 37:644-653 doi:10.1016/j.envint.2011.01.002

Xiao R, Wang G, Zhang Q, Zhang Z (2016) Multi-scale analysis of relationship between landscape pattern and urban river water quality in different seasons Sci Rep 6:25250 doi:10.1038/srep25250

Yates AG, Brua RB, Corriveau J, Culp JM, Chambers PA (2014) Seasonally Driven Variation in Spatial Relationships between Agricultural Land Use and in-Stream Nutrient Concentrations River Research and Applications 30:476-493 doi:10.1002/rra.2646

Zhang W, Pueppke SG, Li H, Geng J, Diao Y, Hyndman DW (2019) Modeling phosphorus sources and transport in a headwater catchment with rapid agricultural expansion Environ Pollut 255 doi:10.1016/j.envpol.2019.113273 
Denominator calculation for $a=1.5$ and $b=1$

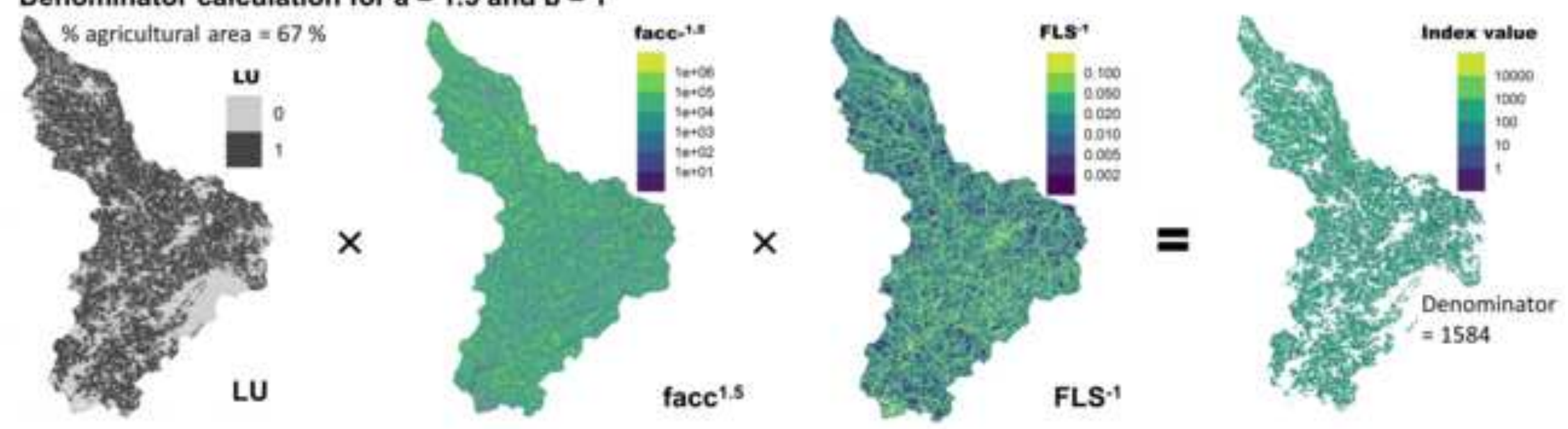

Numerator and $\mathrm{LCl}$ calculation for $\mathrm{a}=1.5$ and $\mathrm{b}=1$

Example of agricultural subcatchments with similar landscape composition but contrasting $\mathrm{LCl}$ values
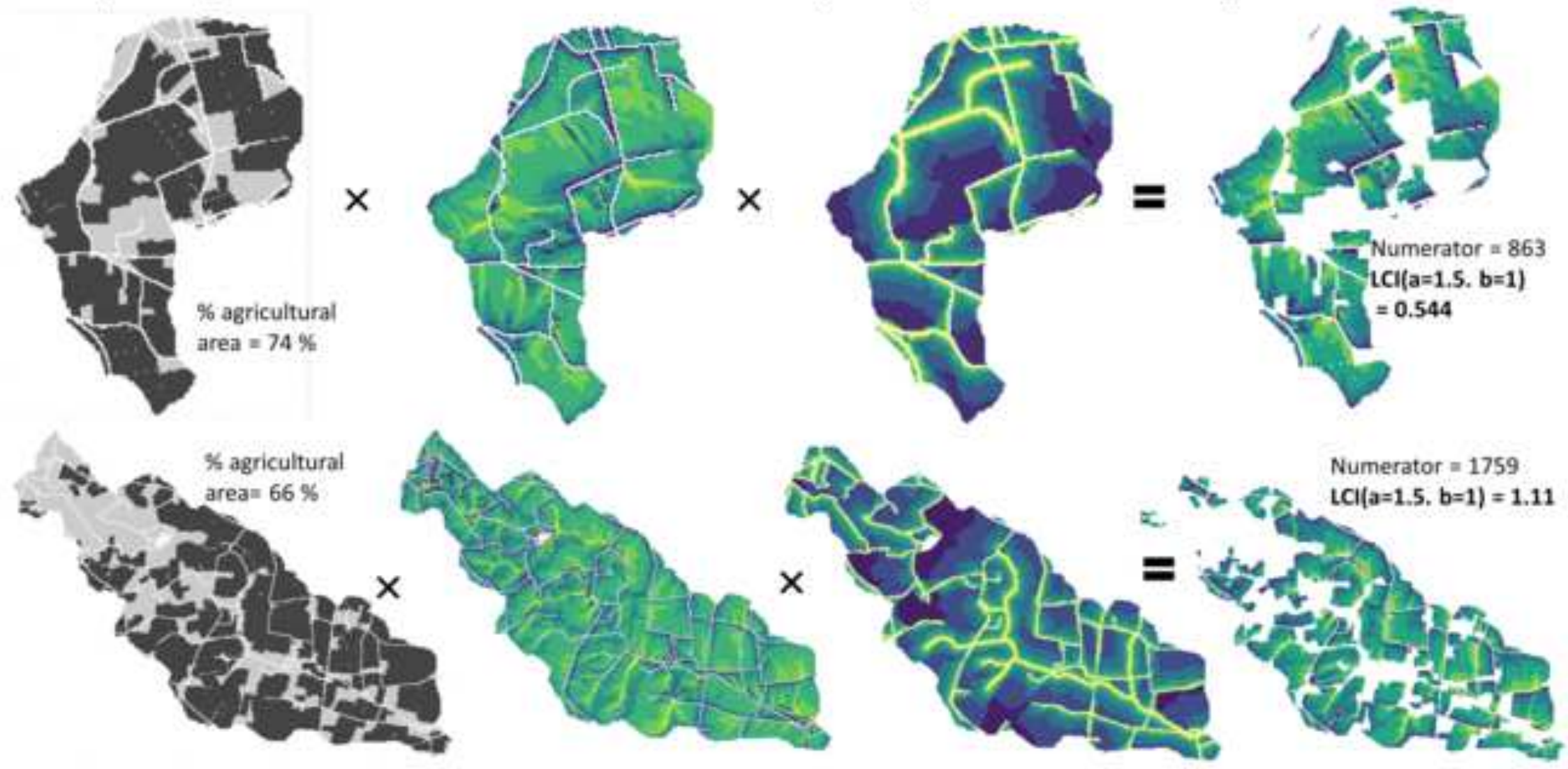


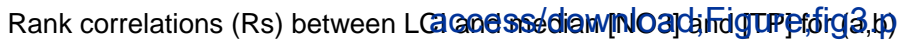

들

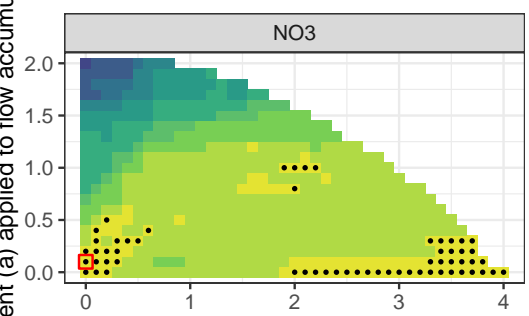

Coefficient (b) applied to inverse distance to stream/ditch

Rs

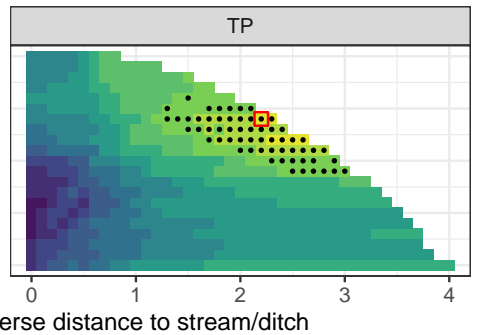

B

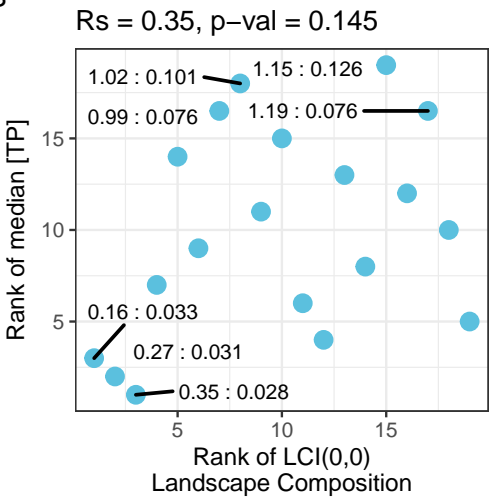

C

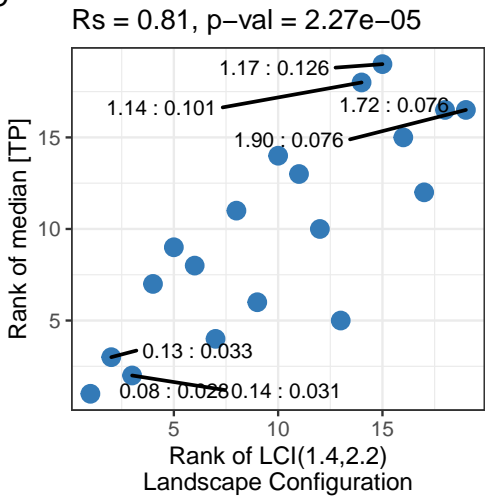


$\mathrm{Fig} 4$

Dynamics of Rs

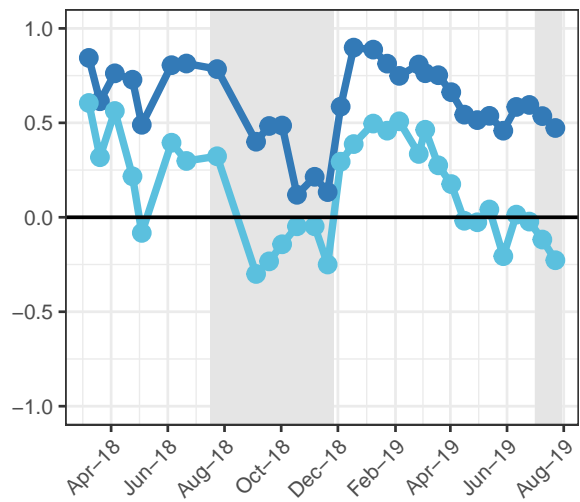

C

Optimal $(a, b)$ for $\mathrm{LCl}$

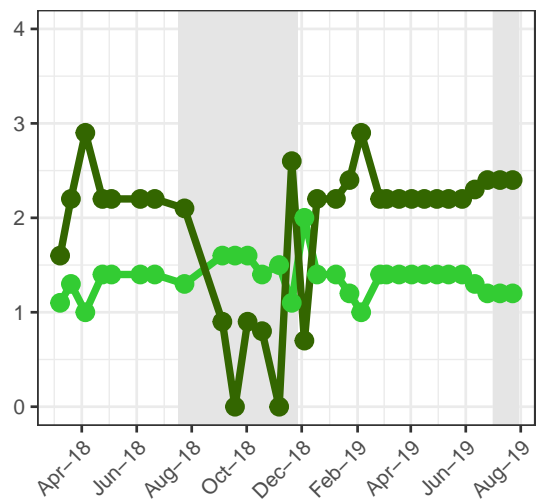

B

Click here to access/download;Figure;fig4.pdf $\underline{\underline{\boldsymbol{*}}}$ Dynamics of associated $p$-values

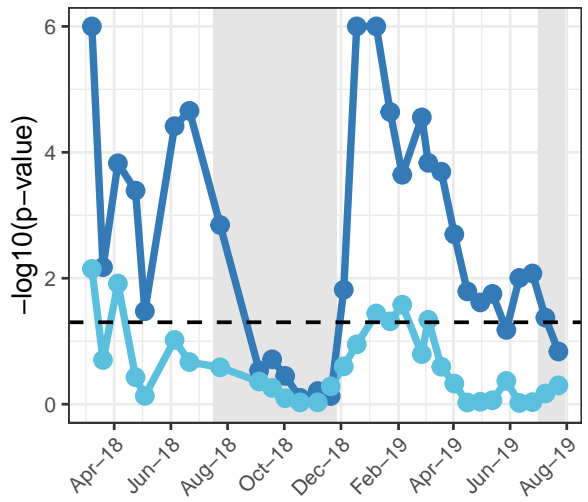

metric

- Landscape

Landscape Configuration

D

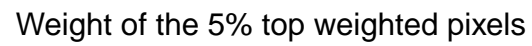

coefficient

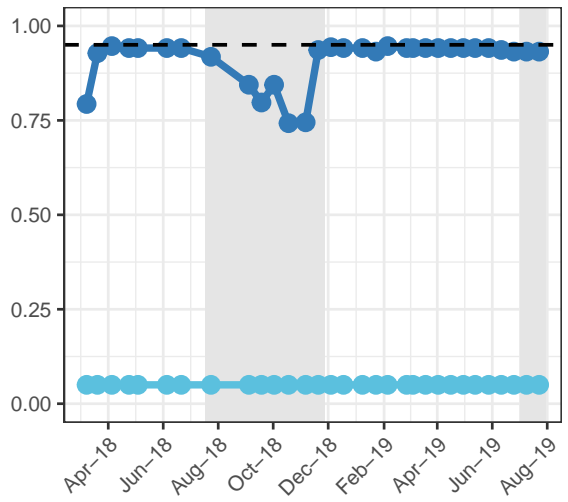

- $a$

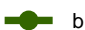


A

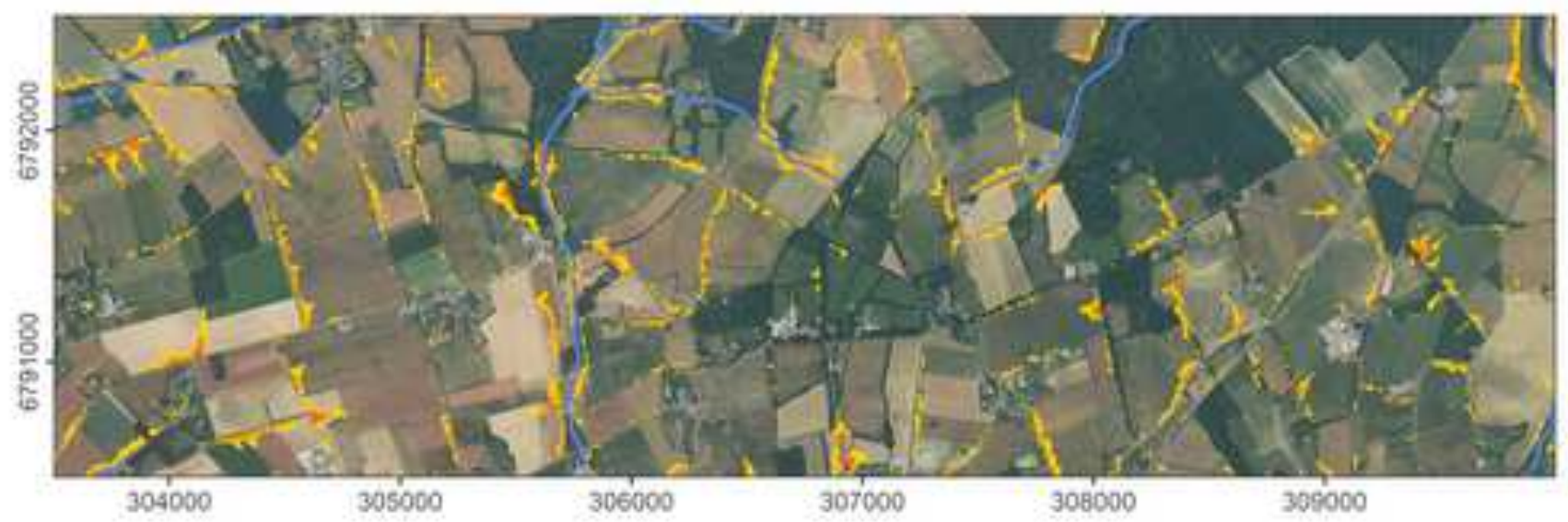

B

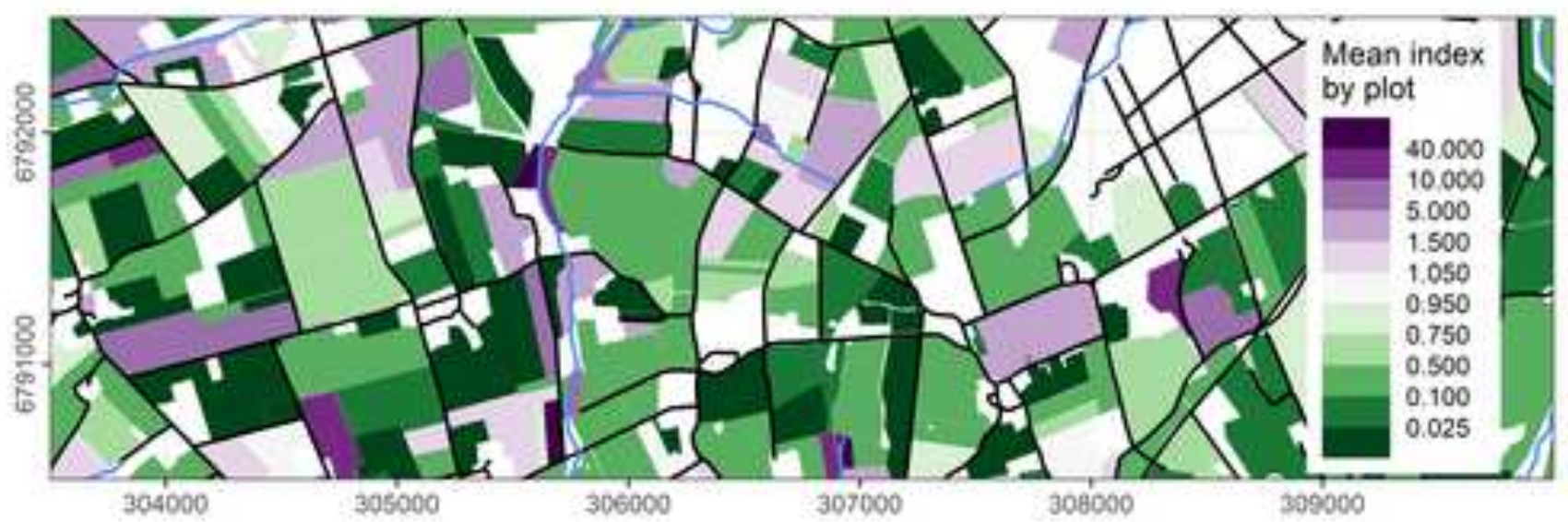

C

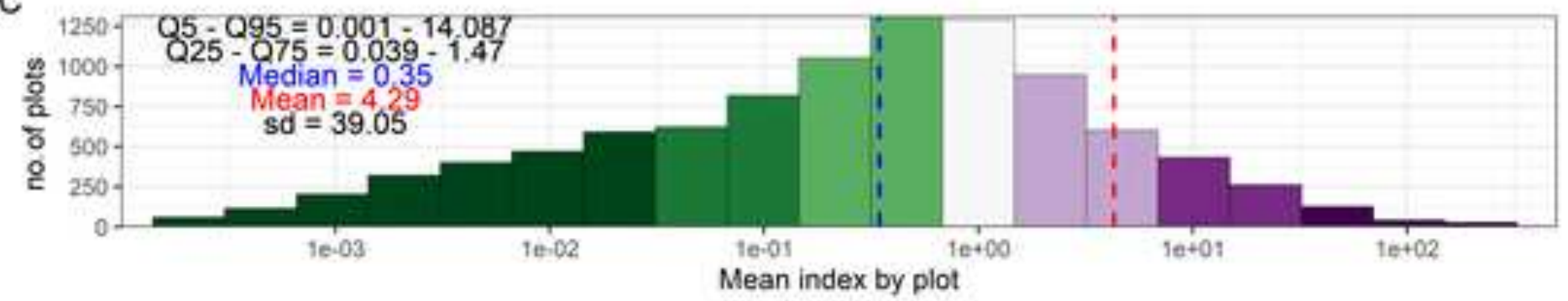

D

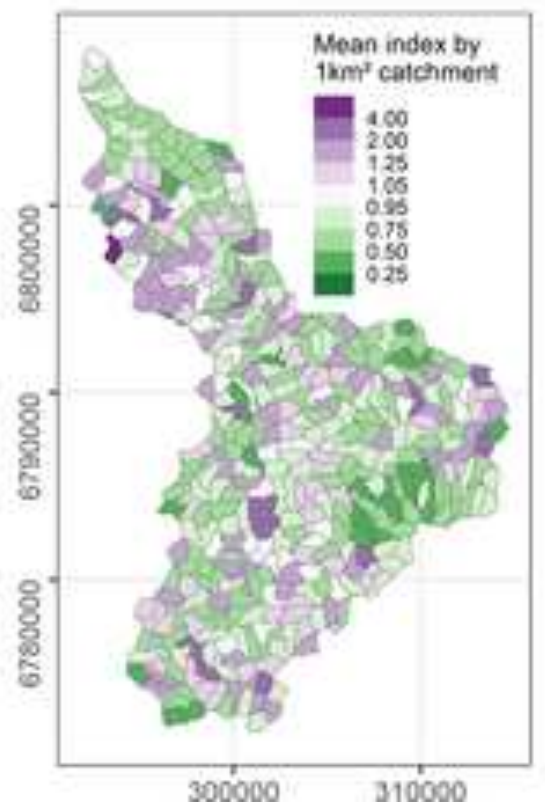

E

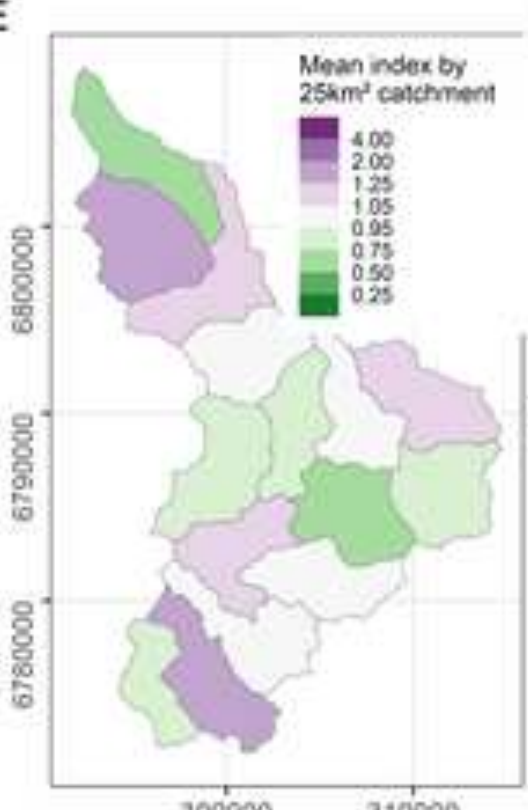

F

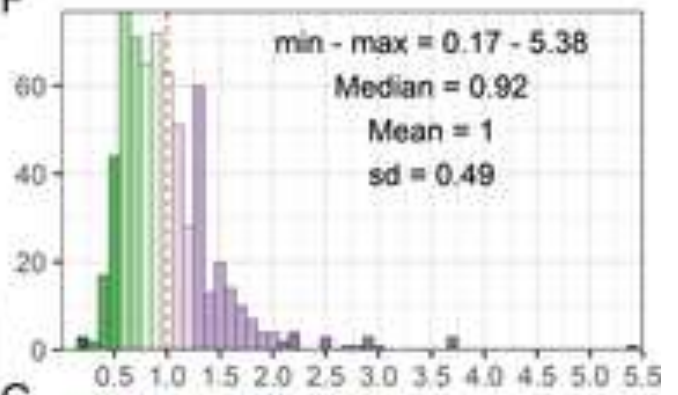

G

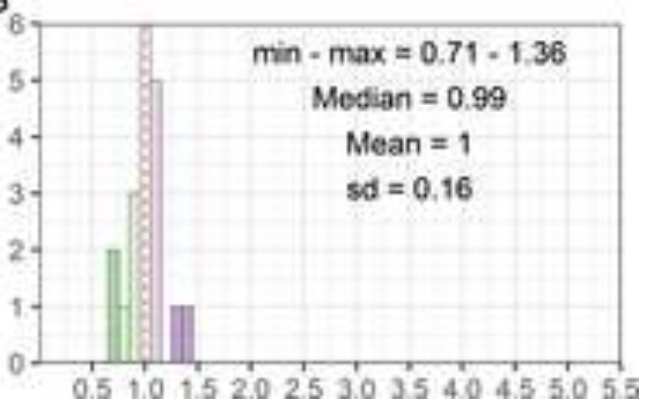




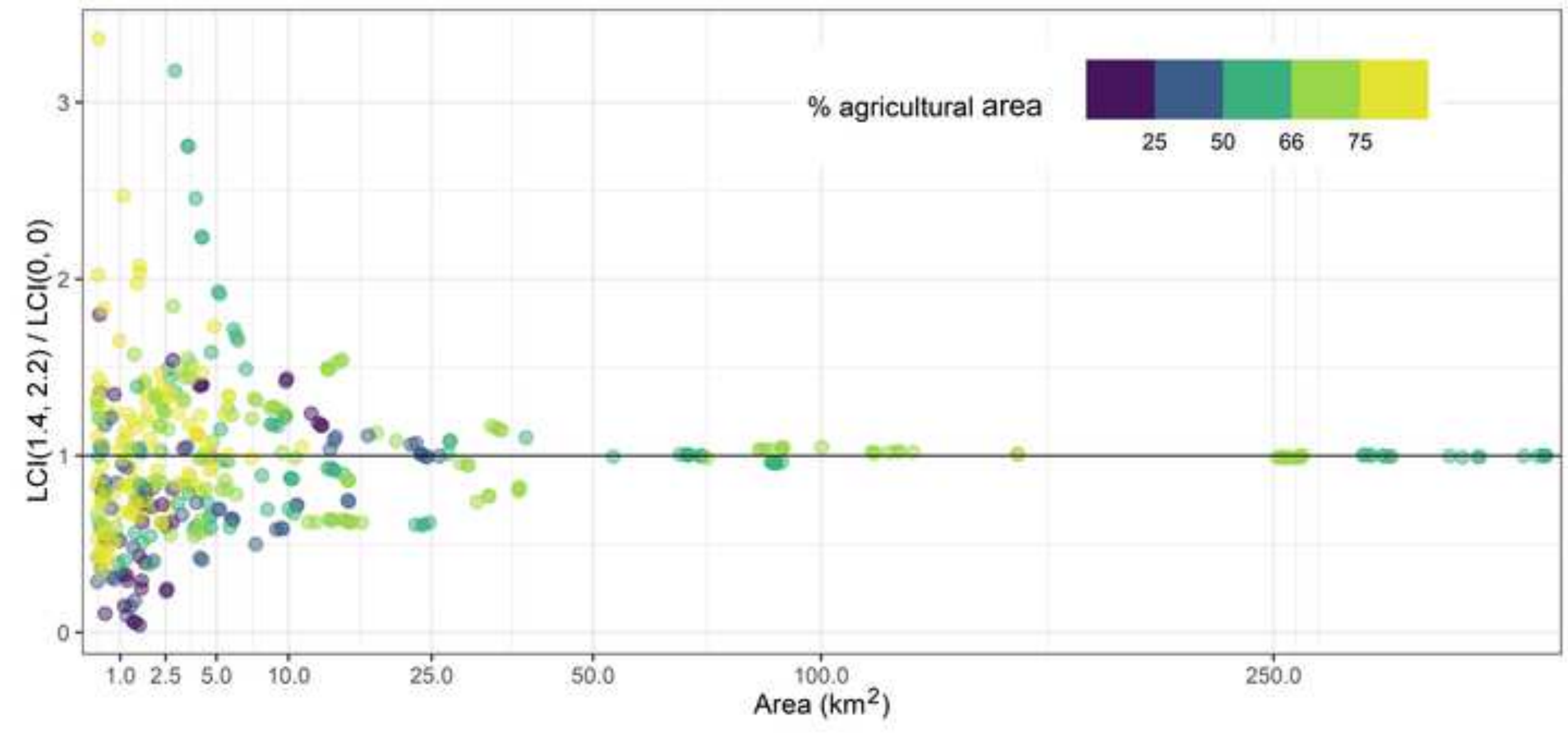




\section{Editor du Jour}

\section{Certificate of English-Language Proofreading}

This certificate confirms that the manuscript entitled "The influence of landscape spatial configuration on nitrogen and phosphorus exports in agricultural catchments" by Antoine Casquin et al. was edited and proofread for correct English-language content by two native speakers of American English.

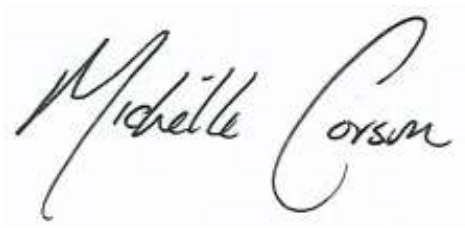

Michelle Corson

29 January 2021

Certificate no. 2021-04

Editor du Jour

33 rue Émile Bernard

35700 Rennes, FRANCE

E-mail: editordujour@yahoo.fr

URL: http://editordujour.corsondna.com/ 
Antoine Casquin

INRAE - UMR SAS / Institut Agro

65 rue de St Brieuc

CS 84215

35042 Rennes Cedex

France

Tel: +33223485142

E-mail: antoine.casquin@inrae.fr

\section{Subject: Submission of a manuscript for evaluation and publication in Landscape Ecology}

Dear Editors,

Enclosed is our manuscript, "The influence of landscape spatial configuration on nitrogen and phosphorus exports in agricultural catchments" by Antoine Casquin et al., which we would like to submit for publication as a Research paper in Landscape Ecology.

This manuscript has not been previously published, in whole or in part, and is not under consideration by another journal. All co-authors - A. Casquin, R. Dupas, S. Gu, E. Couic, G. Gruau and P. Durand - have approved the manuscript and agree with its submission to Landscape Ecology. We had the English proofread by a professional proofreader (“Editor du Jour”; see enclosed English editing certificate).

The spatial variability in nutrient transfer from land to stream in seemingly similar headwater catchments is currently not fully understood, and upscaling results from the plot scale to the catchment scale remains difficult. Our study indicates that including the influence of the spatial configuration of nutrient sources in relation to the hydrographic network is crucial to explore this issue.

We assessed the influence of landscape spatial arrangement on nitrate ( $\mathrm{NO}_{3}{ }^{-}$) and total phosphorus (TP) exports at the catchment scale. We developed a novel landscape configuration index that we optimised based on $\mathrm{NO}_{3}$ and TP concentrations in 19 headwater streams. Results show that the spatial configuration of nutrient sources and sinks in headwaters has a large influence on TP transfers but not $\mathrm{NO}_{3}$ - transfers. We also reveal that the spatial configuration of sources is heterogeneous at small scales $\left(<1 \mathrm{~km}^{2}\right)$ but homogeneous at larger scales $(>$ $50 \mathrm{~km}^{2}$ ), and we discuss the implications of these findings.

This study is based on a recently published dataset entitled Repeated synoptic sampling for water chemistry monitoring in the Yvel catchment, northwestern France. We plan to make the code (R script) available along with the article upon acceptance.

Thank you for considering our manuscript.

Sincerely,

Antoine Casquin 
Click here to access/download

\section{Supplementary material SupMat.docx}

